\title{
France: Selected Issues Paper
}

This Selected Issues paper on France was prepared by a staff team of the International Monetary Fund as background documentation for the periodic consultation with the member country. It is based on the information available at the time it was completed on July 13, 2010. The views expressed in this document are those of the staff team and do not necessarily reflect the views of the government of France or the Executive Board of the IMF.

The policy of publication of staff reports and other documents by the IMF allows for the deletion of market-sensitive information.

\author{
Copies of this report are available to the public from \\ International Monetary Fund • Publication Services \\ $70019^{\text {th }}$ Street, N.W. • Washington, D.C. 20431 \\ Telephone: (202) 623-7430 • Telefax: (202) 623-7201 \\ E-mail: publications@imf.org Internet: http://www.imf.org
}

Price: $\$ 18.00$ a copy

\section{International Monetary Fund Washington, D.C.}




\section{INTERNATIONAL MONETARY FUND}

\section{FRANCE}

\section{Selected Issues}

Prepared by Yingbin Xiao, Irina Tytell, Irina Yakadina, and Kevin Cheng

Approved by the European Department

July 13, 2010

Contents

I. Credit Developments in France and Systemic Linkages of the French Financial Sector...... 2

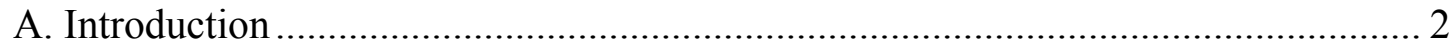

B. Credit Developments in France ........................................................................ 2

C. Systemic Linkages of French banks .................................................................... 10

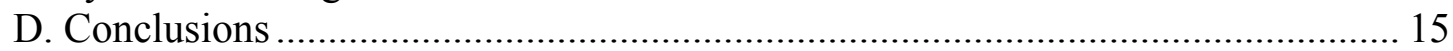

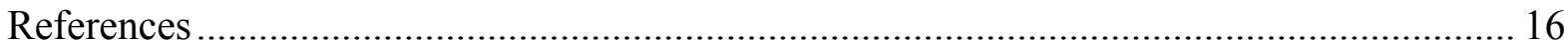

II. France: Lessons from Past Fiscal Consolidation Plans .................................................... 18

A. Introduction: A Long History of Deficits........................................................... 18

B. A First Attempt at a Medium-term Consolidation in 1994-1997 ........................... 21

The First Five-Year Budgetary Plan: The 1994 Reference Law for Public

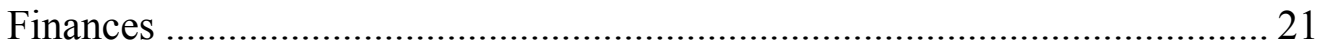

A Mixed Start: 1994-1995 ........................................................................ 22

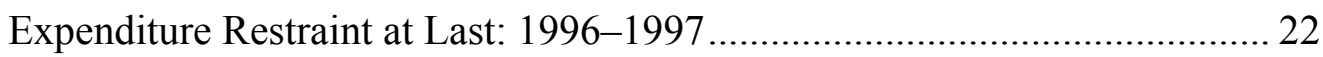

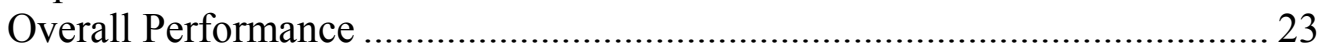

C. A More Systematic Approach to Medium-Term Budgeting: Consolidation

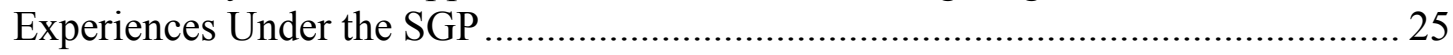

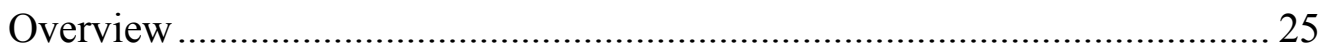

The Composition of Adjustment................................................................. 26

A Closer Look at Macroeconomic Assumptions ............................................... 28

A Closer Look at Spending by Levels of Government................................... 28

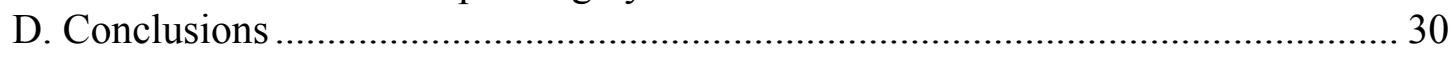

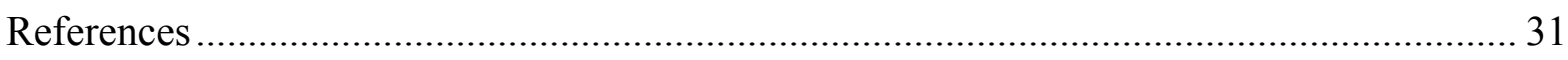

III. Developments in France's External Competitiveness-An Update .................................. 32

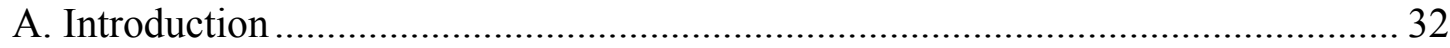

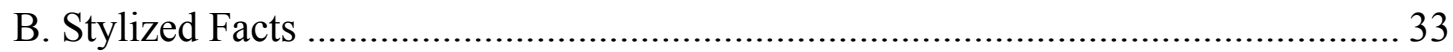

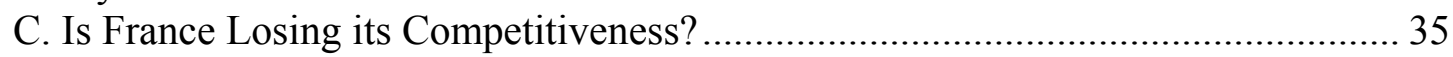

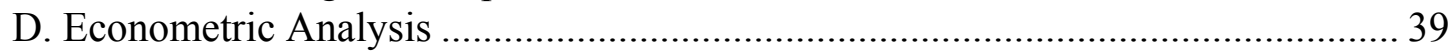

E. Concluding Remarks and Implications................................................................. 42

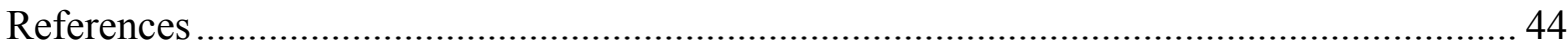




\section{Credit Developments in France and Systemic Linkages of the French FINANCIAL SECTOR ${ }^{1}$}

\section{A. Introduction}

1. This note focuses on two pertinent financial sector concerns in France: (i) credit dynamics in the current recovery period; and (ii) strength and possible systemic implications of the French financial sector's international linkages. The still depressed growth of bank lending, especially to the corporate sector, raises concerns about a possible credit crunch. Using the bank lending survey, surveys of small and medium-sized enterprises (SMEs) access to finance, and inferences from relative developments in prices of loan and bond markets, the note examines whether the drop in credit growth is driven by demand or supply factors. International inter-linkages of the French financial sector have raised concerns about possible systemic implications of turbulences in international markets. The note analyzes the quantitative importance of financial links to large and complex financial institutions in sixteen advanced countries, and uses bank CDS spreads to examine the risk implications of these systemic linkages under extreme stress. It takes into account nonlinearities of risk dependence and aims to control for all other variables that could affect bank risks.

\section{B. Credit Developments in France}

\section{Despite relatively less severe consequences of the crisis and an economic recovery} starting in the second quarter of 2009, bank credit growth to the private sector has only rebounded slightly. With the French economy falling into recession in the second quarter of 2008, bank credit growth to the private sector plunged from the peak of over 13 percent into negative territory for the latter half of 2009 (Figure 1). In the first quarter of 2010, credit to the
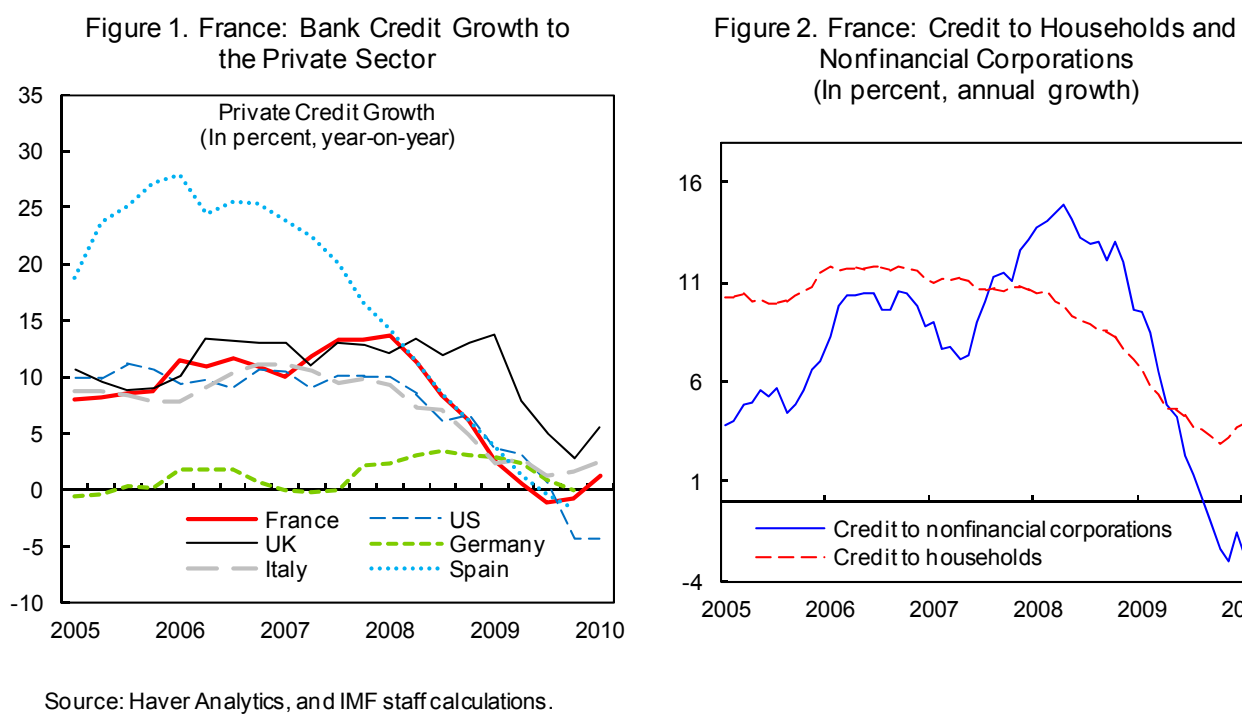

Figure 2. France: Credit to Households and Nonfinancial Corporations (In percent, annual growth)

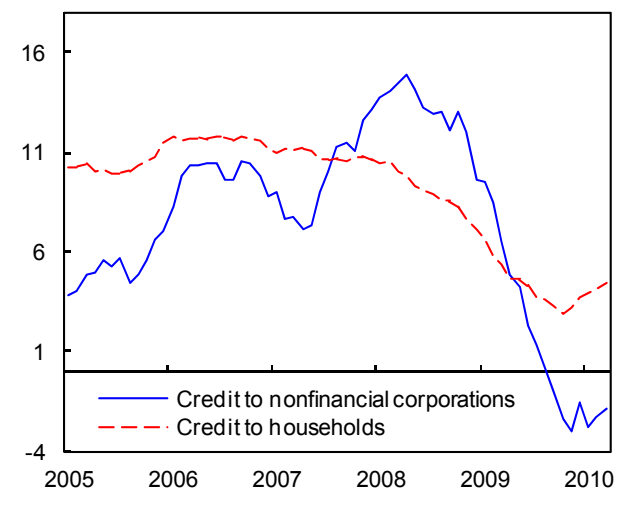

\footnotetext{
${ }^{1}$ Prepared by Yingbin Xiao.
} 
economy expanded slightly. Besides, the slight rebound was driven by bank credit growth to households. Bank credit growth to households started to decelerate following the economic recession and dropped below three percent in October 2009. It has rebounded moderately since then (Figure 2). However, bank credit to corporates has continued to contract.

\section{Recent developments naturally raise concerns about a possible credit crunch.}

Recent studies (IMF (2009a, 2010)) argue that a credit crunch is likely to happen after financial crises as a result of bank losses and recapitalization needs, which would constrain bank loan supply. The negative feedback loop between the financial sector and the real economy in turn implies that a credit crunch would weaken economic recovery, especially for economies relying mainly on bank financing.

4. However, separating loan supply and demand factors is notoriously difficult at the aggregate level. A large literature on cyclicality of bank loans has met with limited success in disentangling the two since the demand for loans may fall during recessions because the set of firms relying on bank loans differs from the set of firms that do not. Without comprehensive disaggregated data at hand, the note focuses on presenting some evidence and observations from the substitution between bank and bond financing, the bank lending survey, and surveys on SMEs' access to finance.

5. Firms are switching from bank loans to corporate bonds. Total credit to corporates increased from 57 percent of nominal GDP before the crisis to 61 percent in the last two quarters of 2009. The share of bank loans in total credit to corporates rose from the pre-crisis level of 62 percent to 68 percent in the first quarter of 2009, but fell to 66 percent in the last quarter of 2009 (Figure 3). The growth of corporate loans dipped into negative territory since the third quarter of 2009 mostly driven by cash credit, while corporate bond issuance started to pick up since the beginning of 2009. Historically, corporate bond issuance has been more volatile than loans. The substitution not only increased the divergence over recent quarters, but also stabilized total corporate financing.

Figure 3. France: Bank Loans to Total Credit to Nonfinancial Corporations and Nonfinancial Sector (In percent)

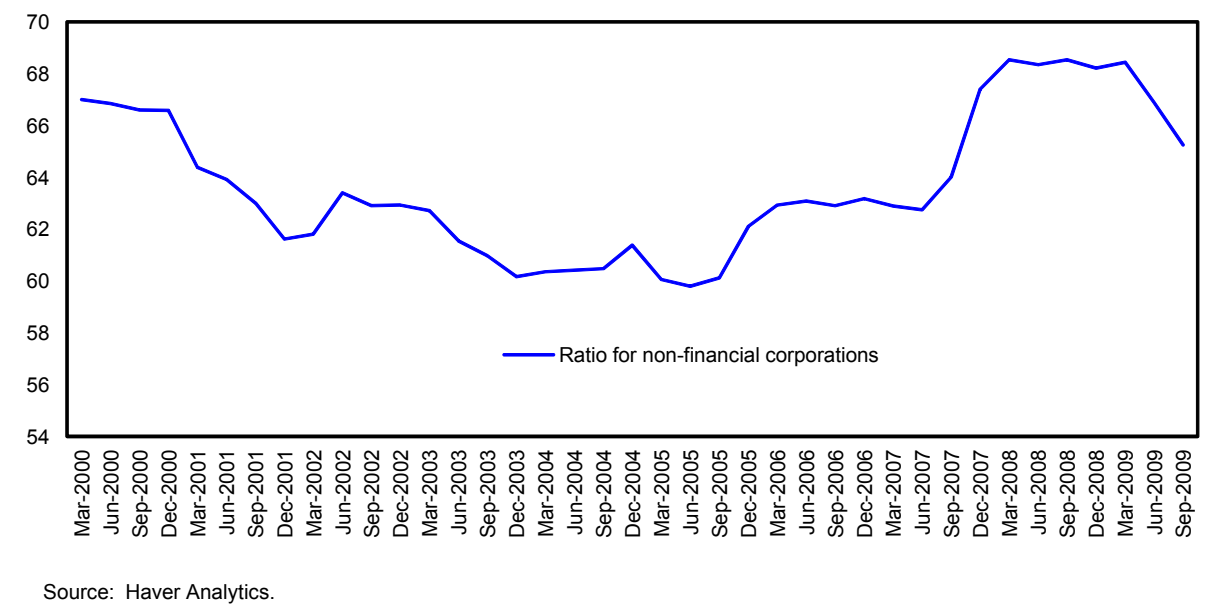




\section{Although at first sight the substitution between bond and bank financing seems to} indicate bank supply constraints, the change of relative pricing of bonds and loans seems to indicate other possibilities. Since changes in credit demand should affect different types of credit in broadly the same way, the shift from loans to bonds may imply bank supply constraints (Kashyap, Stein, and Wilcox (1993)). However, at the aggregate level, the shift could also be brought about by the redirecting of credit from SMEs to large firms since changes in the financing cost are likely to hurt SMEs more due to information asymmetries (Oliner and Rudebusch (1996)). Given that the financing cost of both bank loans and corporate bonds have come down substantially, it would be useful to look at relative pricing. The ideal comparison would be loans and bonds of similar credit risk and maturity. Without such ideal data at hand, an indicative series of relative pricing measured by composite rates is constructed by comparing the lending rates with bond yields. The substitution reflects the improvement in accessing corporate bond markets (Figure 4), but also seems to be partly driven by the change in the relative cost of loans and bonds. The negative growth of corporate loans happened at the time when the relative price of loan-to-bond bounced off lows (Figure 5). In addition, firms may turn to bond markets for diversification in their financing and tap them on an irregular basis once their financing requirements are met.

Figure 4. France: Composite Corporate Bond Yields

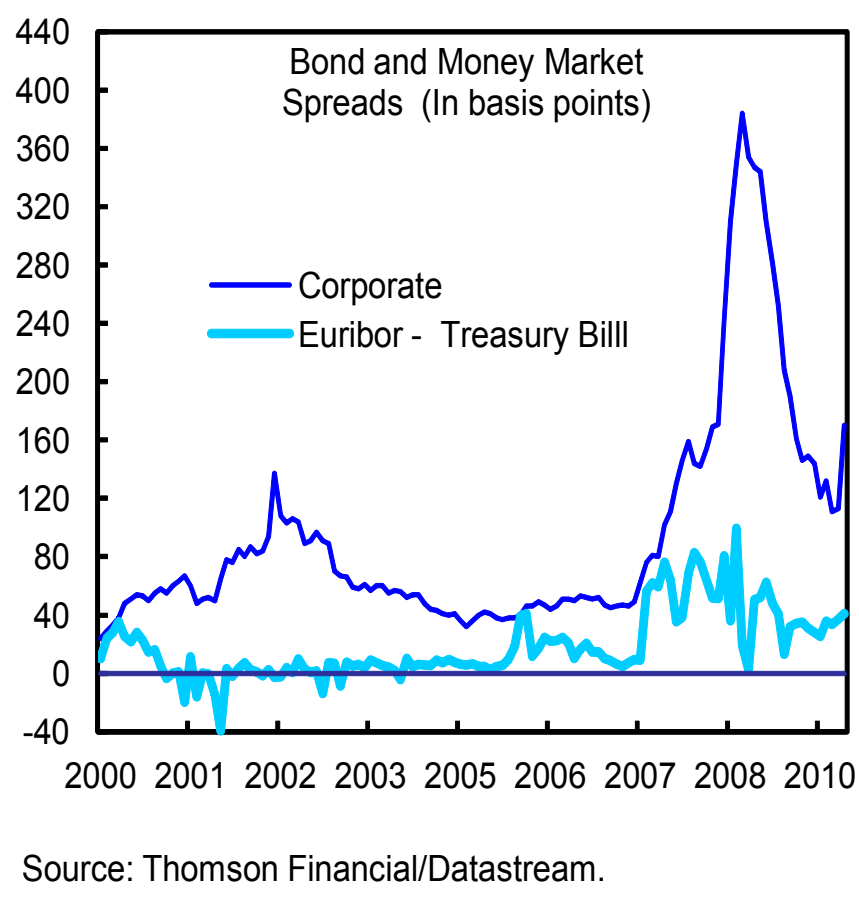

\section{The bank lending survey provides additional information on bank credit supply} and demand factors. The Banque de France $(\mathrm{BdF})$ bank lending survey is comparable to the ECB bank lending survey for the euro area, which was launched in January 2003 and followed the U. S. senior loan officer opinion survey undertaken by the Federal Reserve since 1967. The survey shows the net percentage of opinions for both changes in bank lending criteria and loan demand. Several studies have shown the positive relationship of the survey results with credit developments (Lown and Morgan (2006), Bayoumi and Melander (2008), Lacroix and Montornés (2009), De Bondt et al (2010)). 
Figure 5. France: Corporate Bonds vs. Corporate Loans
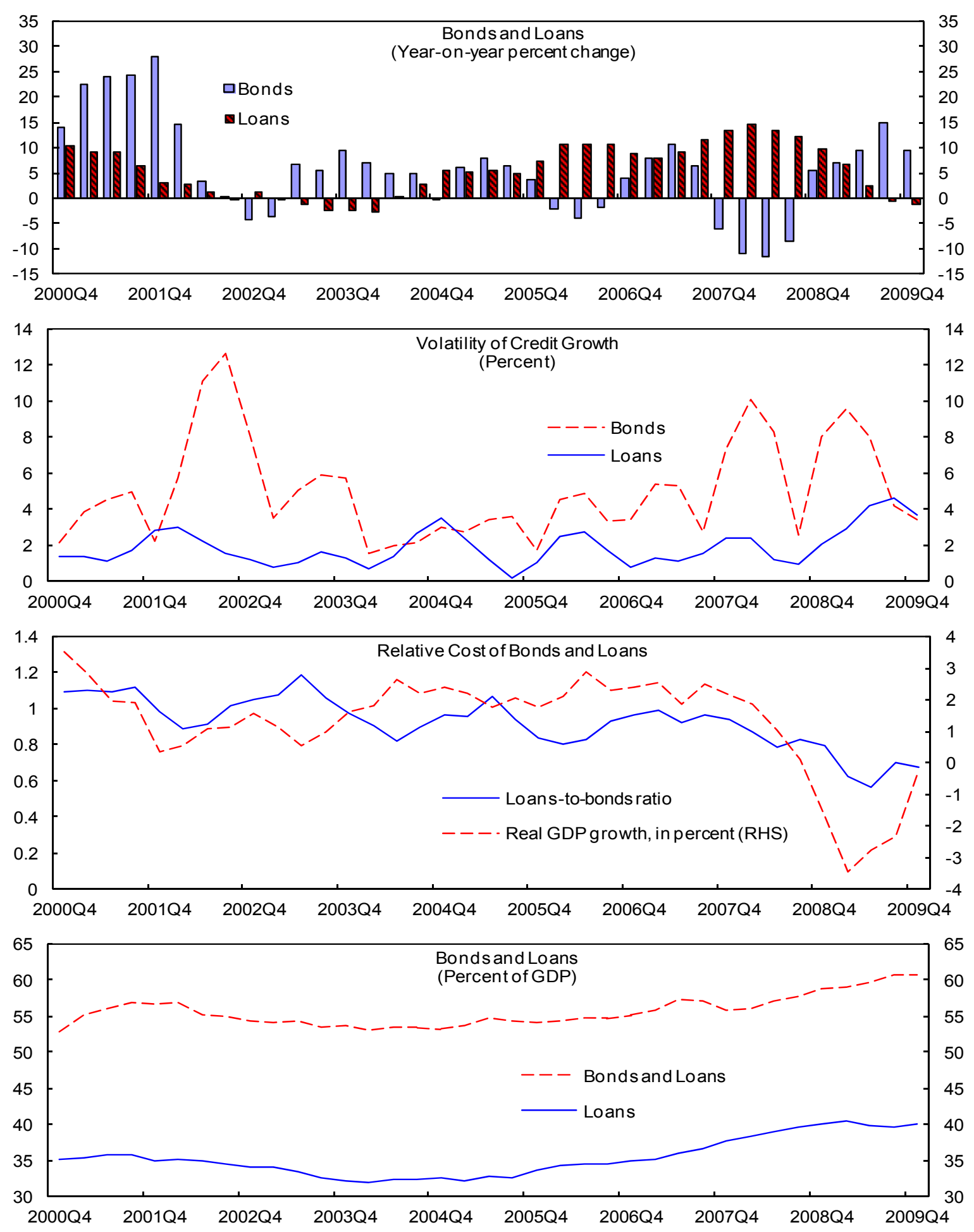

Source: Haver Analytics 
8. Lending criteria are easing against less declining or rising demand. The BdF lending survey has shown that French banks registered an outright easing for corporate loans to large firms in the third quarter of 2009 and for corporate loans to SMEs in the fourth quarter of 2009 (Figure 6). French banks no longer tightened their lending standards for consumer loans starting from the third quarter of 2009 and eased lending standards for house purchase loans in the fourth quarter of 2009 (Figure 7). The evolution of lending criteria stands in contrast to that of the euro area: the latest ECB lending survey shows that euro area banks are still tightening lending standards on a net basis for both corporate and household loans, although very moderately. Using a bridge model to analyze the French bank lending survey, Lacroix and Montornés (2009) argue that both the tightening of lending criteria and declining demand have led to a slowdown of lending and that demand factors seem to have been more important in the case of corporate lending.

\section{While lending standards in France have eased, the degree of easing for SMEs} seems to be less than for large firms. In addition, a credit crunch is more likely to take place for SMEs than large firms since SMEs do not have the alternative of financing themselves through corporate bond markets. Without direct SME loan data at hand, we use the ECB survey on the access to finance of SMEs in the euro area (2009, 2010). The survey started in 2009 and provides evidence on the financial situation, financing needs, and access to finance of SMEs in the euro area.

10. The ECB survey on the access to finance of SMEs in the euro area for the first and second half of 2009 seems to show that access to finance for French SMEs has improved and was better than for their euro area peers. Specifically, the survey shows that the availability of bank loans to French SMEs was least negative for 2009 and saw an improvement in the second half compared to the first half of 2009 (Figure 8). In the second half of 2009, 80 percent of the French SMEs reported that they had received the entire amount of the bank loan they had applied for, which was the highest rate among the euro area countries. The rejection rate fell from 12 percent in the first half of 2009 to 7 percent in the second half of the year, which was the lowest rate among the euro area countries. Comparing with expectations six months ago, SMEs in France were more optimistic regarding their access to bank loans in the first half of 2010 than SMEs in the other euro area countries, and on balance expected an improvement in access.

11. This outcome may partly reflect the impact of policy measures taken. Efforts to boost lending to the SME sector and to very small companies have been pursued. The largest five French banks committed to expanding credit to these companies by three percent in 2009 than 2008. The authorities took actions to alleviate working capital shortages by capping payment delays to 45 days, doubling moratory interests and putting in place other legal deterrents to repayment delays. To enhance SMEs' access to liquidity, especially bank lending, the government has increased guarantee programs run by $O S E O$ so as to allow it to cover up to $€ 8$ billion of new loans targeted to SMEs and linked to short-term credits. In addition, to assist SMEs to resolve their liquidity problems by maintaining or obtaining credit, the office 
Figure 6. France: Corporate Lending Standards and Demand
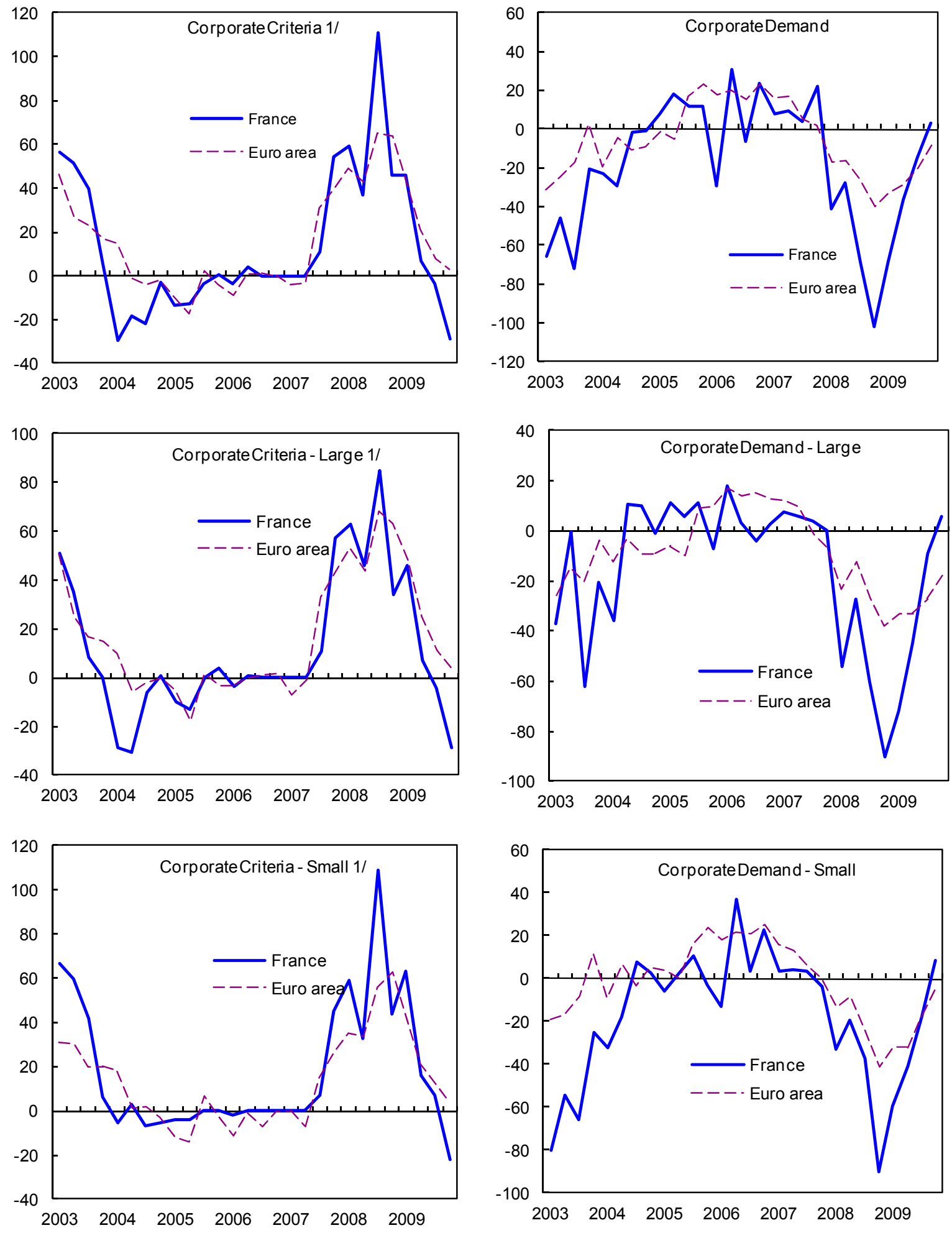

Sources: Global Insight/Datainsight; ECB and Bank of France. 1/ Criteria above (below) zero indicates tightening (loosening) of lending standards compared to previous 3 months. 
Figure 7. France: Consumer Lending Standards and Demand
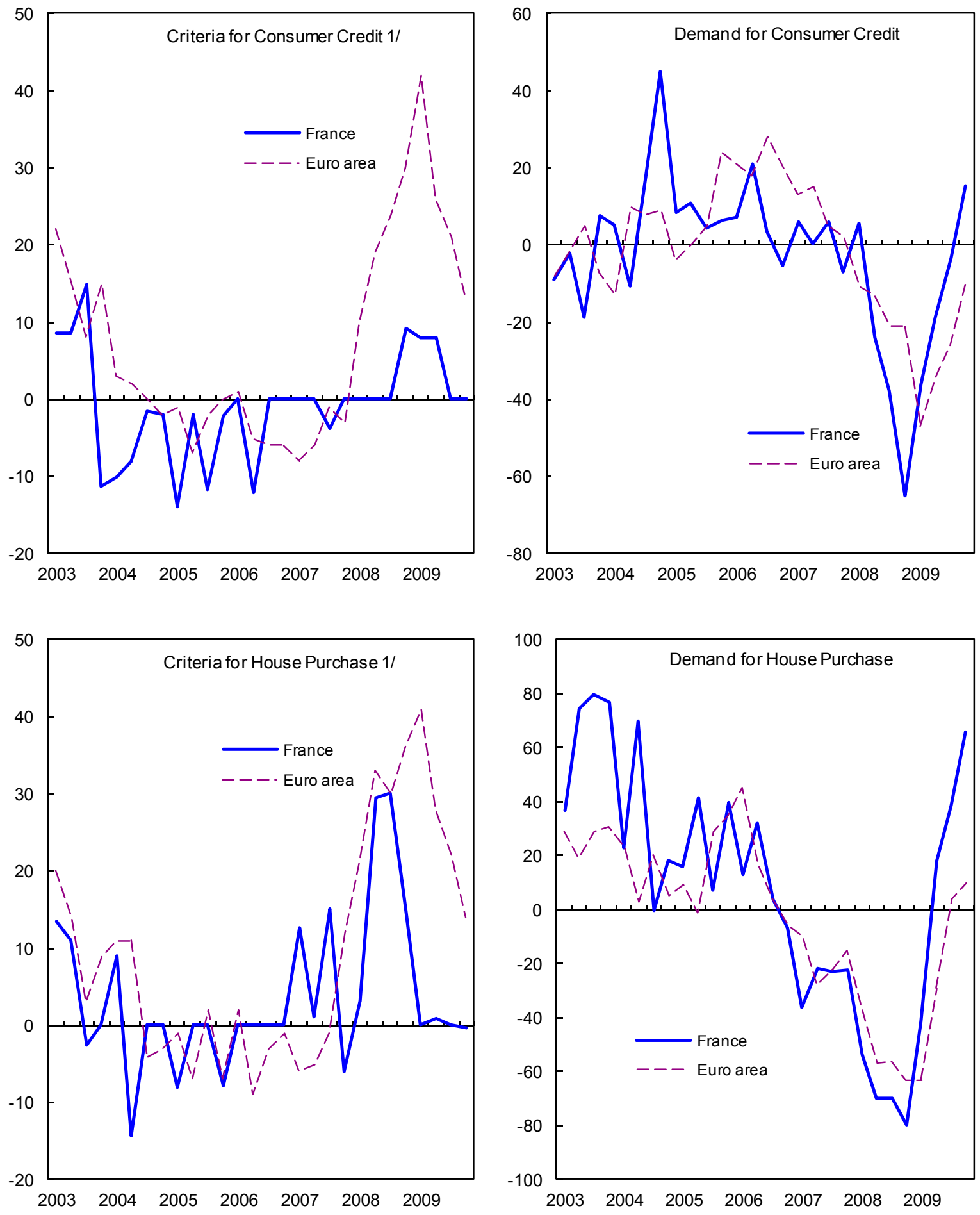

Sources: Global In sight/Datainsight; ECB and Bank of France.

1/ Criteria above (below) zero indicates tightening (loosening) of lending standards compared to previous 3 months. 
Figure 8. France: Access to Finance by SMEs, 2009
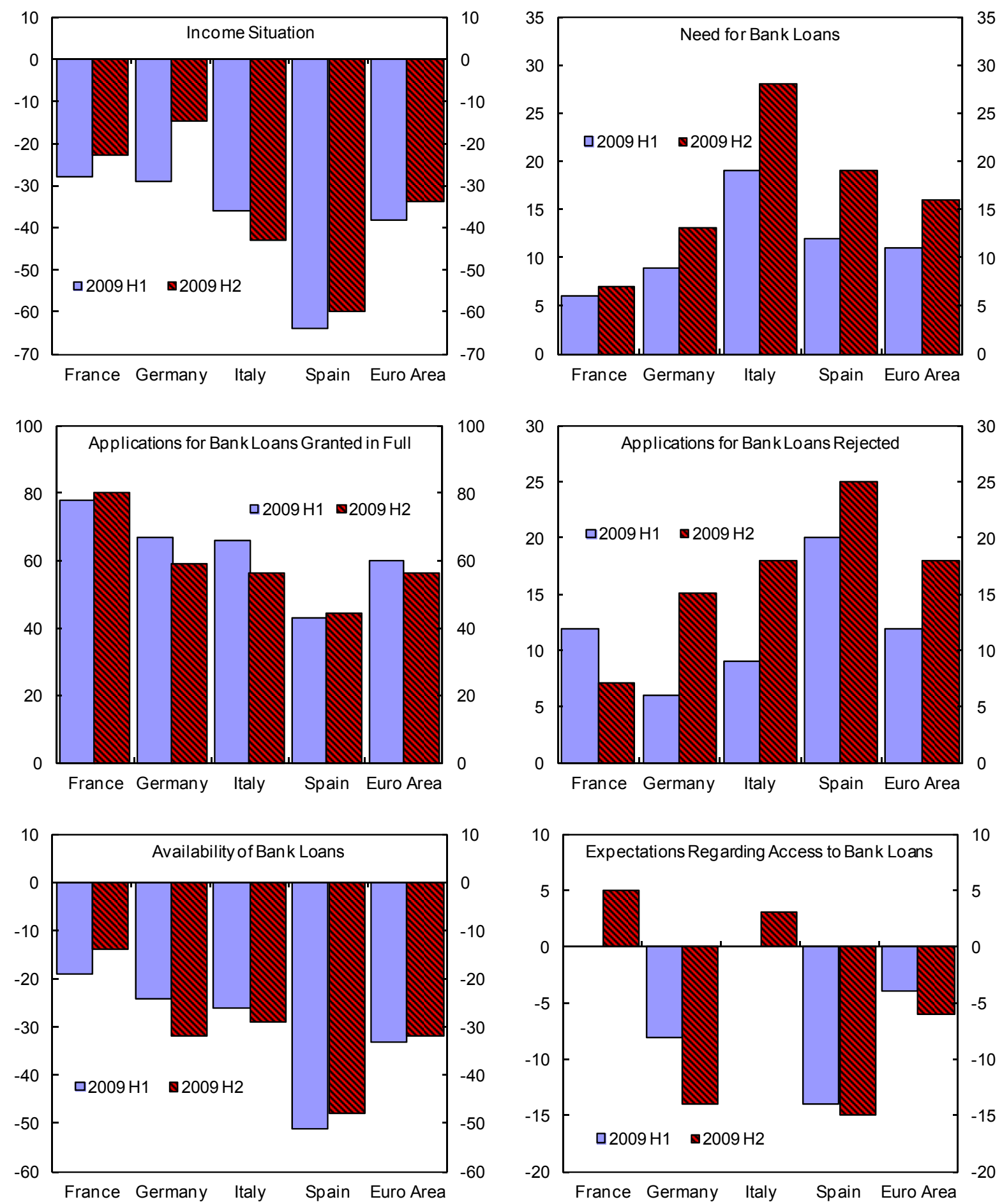

Source: ECB. 
of the Médiateur du Crédit was set up in late 2008 and will run until the end of 2010 (Liebert (2009)). The Médiateur du Crédit can intervene at national and regional levels to ease difficulties and help resolve conflicts between firms seeking bank funding and the banks. The rate of successful mediation within 15 days was reported to be 66 percent. The Médiateur du Credit has also helped improve the transparency and functioning of credit insurance.

\section{Systemic Linkages of French banks}

\section{One of the lessons learned from the current global financial crisis is the lack of} systemic lens in regulation. Systemic risk is a negative externality imposed by each financial firm on the system. It can be thought of as widespread failures of financial institutions or freezing up of capital markets that can substantially reduce the supply of capital to the real economy. Systemic risk concerns were raised in both the rescue of Bear Stearns and the bankruptcy of Lehman Brothers.

\section{This points to the importance of assessing the systemic implications of} international financial interconnections. The strong financial linkages arising from the increasing globalization and complexity of financial institutions, instruments, and markets could be a double-edged sword. The interconnections could not only facilitate better credit allocation and risk diversification, but also make the stress in one part of the financial system spread more quickly and widely. There has been a flurry of proposals to address systemic risk (IMF/BIS/FSB (2009), Lepetit (2010)). However, to implement an appropriate package of measures, including capital and liquidity surcharges or financial levies and taxes, an appropriate approach to measuring systemic importance is called for. The assessment could be based on individual bank characteristics such as leverage, asset quality, size, and substitutability; on statistical measures; and on measures of complexity and connectedness that define large, complex financial institutions. Systemic risk depends on the inter-linkages within the financial system and across the various sources of vulnerability, and may well be greater than the sum of the risks facing individual institutions.

\section{As the connectedness among financial institutions tends to be nonlinear, nonlinear} methodologies need to be used. One of such methods is quantile regression. In contrast to the OLS regression methods, which reveal mean relationships among dependent variables and independent variables, quantile regression reveals relationships among dependent variables and independent variables across different quantiles of the sample distribution. This is particularly useful to analyze codependence during distress periods when systemic risk is more of a concern. Since during distress periods, all variables will display large deviations from the mean, relationships uncovered by the quantile regression corresponding to high quantiles are more appropriate and useful than mean relationships uncovered by OLS regression. Quantile regression was first introduced by Koenker $(1978,2005)$ and has recently been applied in systemic financial risk studies of American banks (Adrian and Brunnermeier (2009) and IMF (2009b)). 
15. This note uses a similar methodology to analyze the systemic connections of major French banks with 41 banks in 16 countries. The French banks included are BNP Paribas (BNPP), Credit Agricole (CA), Societie Generale (SG), and Natixis (NA). The foreign banks included in the analysis are large and complex financial institutions. They are Erste, Raiffeisen (Austria); Fortis, KBC (Belgium); Danske (Denmark); Commerzbank, Deutsche Bank (Germany); EFG Eurobank, National Bank of Greece (Greece); Allied Irish Bank, Anglo Irish Bank (Ireland); Banca Intesa Sampaolo, UBI, Unicredit (Italy); Mizuho, Sumitomo (Japan), ABN Amro (the Netherlands), DNB Nor (Norway), CGD, BCP (Portugal); BBVA, Banco Popular Espanol, Banco de Sabadell, Banco Santander, Bankinter (Spain); Nordea, Svenska, SEB (Sweden); Credit Suisse, UBS (Switzerland); Barclays, HSBC, Lloyds, RBS, Standard Chartered (the U.K.); and Bank of America, Citigroup, Goldman Sachs, JP Morgan Chase, Morgan Stanley, Wells Fargo (the U.S.) An illustration of the nonlinear method is shown in Figure 9. It is clear that when CDS spreads are in the low quantile, (i.e. calm time), the linkage is low; while when CDS spreads are in the high quantile, (i.e. stress time), the linkage is high.

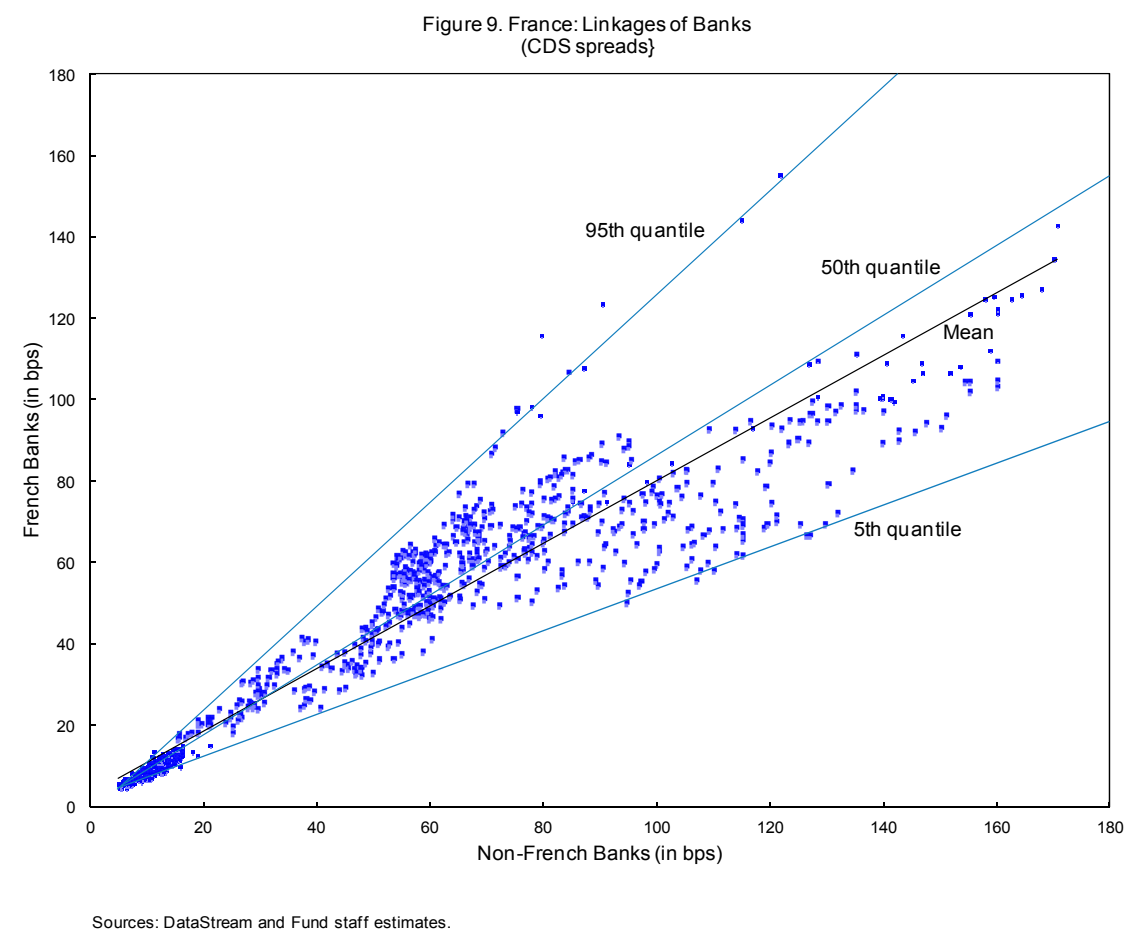

16. The sample consists of daily observations covering the period between January 1, 2004 and May 10, 2010. The dependent variables are five-year CDS spreads of each French bank. The independent variables are five-year CDS spreads of each non-French bank and a set of control variables. These control variables aim to capture both bank-specific and French market-specific risk factors.

17. The control variables are selected based on theoretical and empirical studies in the literature (Fama and French (1989, 1993), Collin-Dufresne, Goldstein, Martin (2001), Xiao (2008, 2009)). To proxy liquidity risk, the bid-ask spreads of each bank's CDS premium are used. The wider is the bid-ask spread, the higher is the liquidity risk. To proxy general risk 
aversion, the implied volatility index (VIX) of CAC 40 from the NYSE Euronext is used. The higher is the index, the higher is the risk aversion of the market. As can be seen from Figure 10 below, VIX of CAC 40 moves closely with the VIX of S\&P 500 from the Chicago Board of Trade. To proxy counterparty risk in the interbank market, Euribor spread measured as the difference between the one-year Euribor spread over the one-year constant-maturity French treasury yield. The wider is the Euribor spread, the higher is the counterparty risk in the interbank market. To proxy the business cycle, the slope of the French yield curve measured as the difference between 10-year and three-month French treasury rates is used. The steeper is the slope of the yield curve, the more likely the economy is in a upturn. The expectation of future economic performance is proxied by the SBF 250 index return. The higher the return, the lower is the credit risk, as the default risk is a function of the value and volatility of equity and the distress barrier.

Figure 10. France: VIX of CAC 40 vs. VIX of S\&P 500

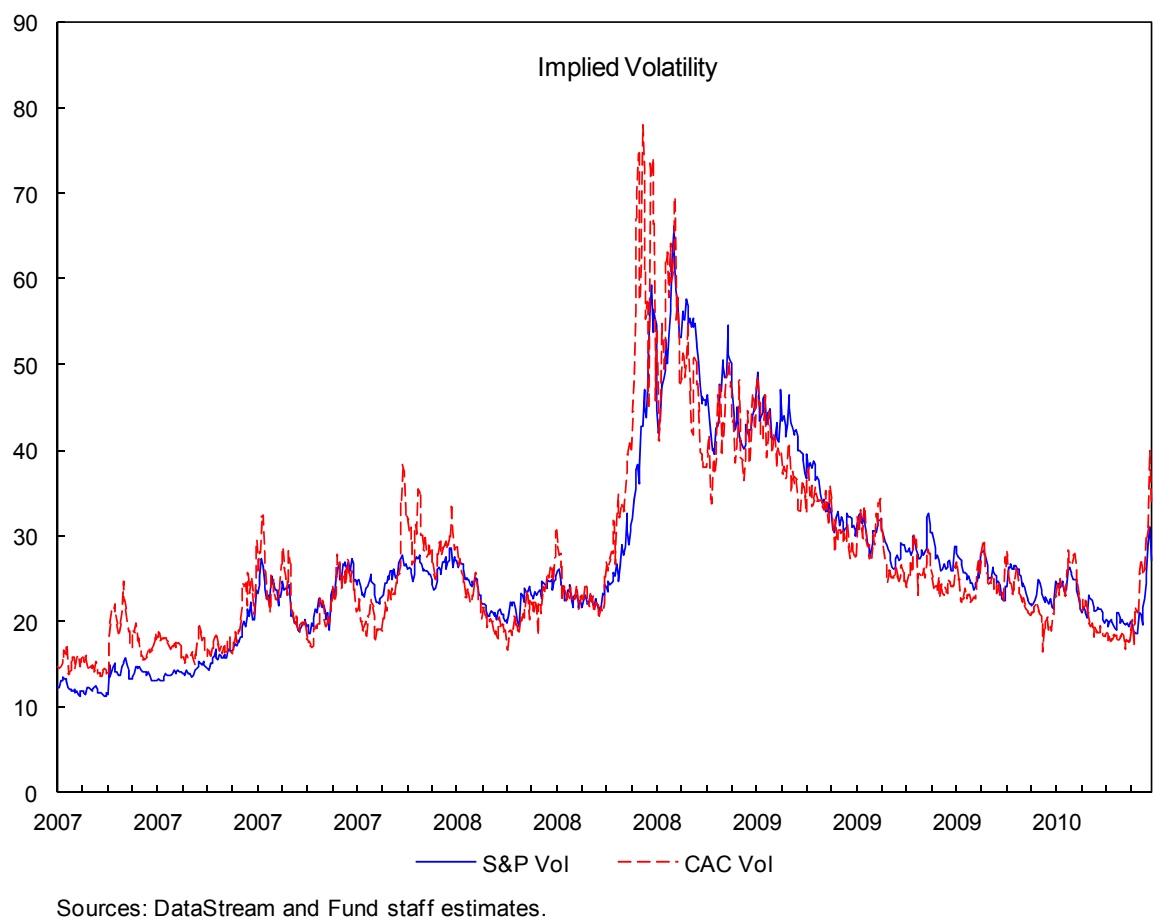

The baseline quantile regression is as follows:

$\mathrm{Ym}=\alpha+\beta_{1} \mathrm{LQm}+\beta_{2} \mathrm{RA}+\beta_{3} \mathrm{ES}+\beta_{4} \mathrm{SL}+\beta_{5} \mathrm{SR}+\varepsilon$

Where

Ym is the CDS spread of French bank m;

LQ is the bid-ask spread of French bank m;

RA is the implied volatility index of CAC 40;

ES is the Euribor spread; 
SL is the slope of the yield curve;

$\mathrm{SR}$ is the SBF 250 index return.

18. Table 1 shows the baseline quantile regression results averaged across four French banks. The quantile is set to be 95th quantile, a common stress level by risk management standards. All standard errors are bootstrapped so that the estimates are robust even under circumstances that residuals and explanatory variables are not independent. As can be seen from Table 1, all coefficients have the expected signs and are statistically significant.

Table 1. Baseline Quantile Regression Results

\begin{tabular}{l|ll}
\hline & Coefficient & $P$ value \\
\hline LQ & 5.21 & 0.00 \\
RA & 0.88 & 0.00 \\
ES & 0.91 & 0.00 \\
SL & -0.12 & 0.09 \\
SR & -0.48 & 0.08 \\
Pseudo R-squared & 0.71 & \\
\hline
\end{tabular}

Sources: Fund staff estimates.

In the next step, the baseline regression is augmented with each non-French bank to control for all the above variables.

$\mathrm{Ym}=\alpha+\beta_{1} \mathrm{LQm}+\beta_{2} \mathrm{RA}+\beta_{3} \mathrm{ES}+\beta_{4} \mathrm{SL}+\beta_{5} \mathrm{SR}+\beta_{6} \mathrm{CDSn}+\varepsilon$

Where

CDSn is the CDS spread of non-French bank n.

Using coefficients from the $95^{\text {th }}$ quantile regression, we can get the predicted spreads of each French bank conditional on each foreign bank at the $95^{\text {th }}$ quantile (a total of 164 predictions). The percentage difference between the predicted and actual spreads at the $95^{\text {th }}$ quantile indicates the risk dependence among banks.

19. Figure 11 shows the distribution of estimated conditional risk. In particular, after controlling for all the other variables, the direct and/or indirect linkages could lead to an average increase in CDS spreads of 56 percent under extreme stress. The slightly right skewedness indicates that the median increase is somewhat higher. The distribution is in a double-hump shape, implying different repricing of risk depending on the strength of direct and/or indirect linkages of French banks with other large and complex financial institutions. 
Figure 11. France: Distribution of Conditional Risk Estimate

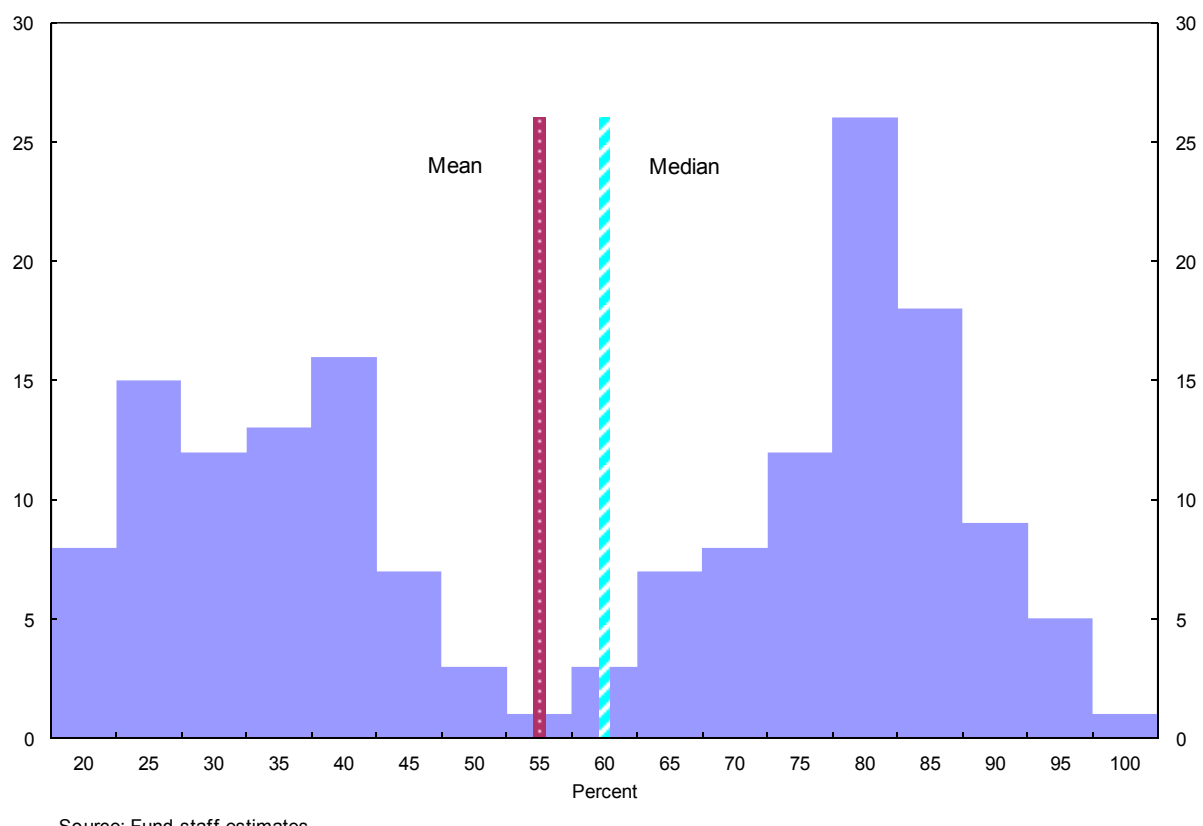

20. Figure 12 shows the estimated conditional risk depending on the countries under stress. As expected, banks in different countries may have different impact on risks of French banks under extreme stress. U.S. banks have the largest impact while Danish banks have the smallest impact. The impact could be considerable in some cases, but is likely to be manageable since French banks have withstood the subprime induced global financial crisis comparatively well and thus appear to have the relatively moderate risk to begin with.

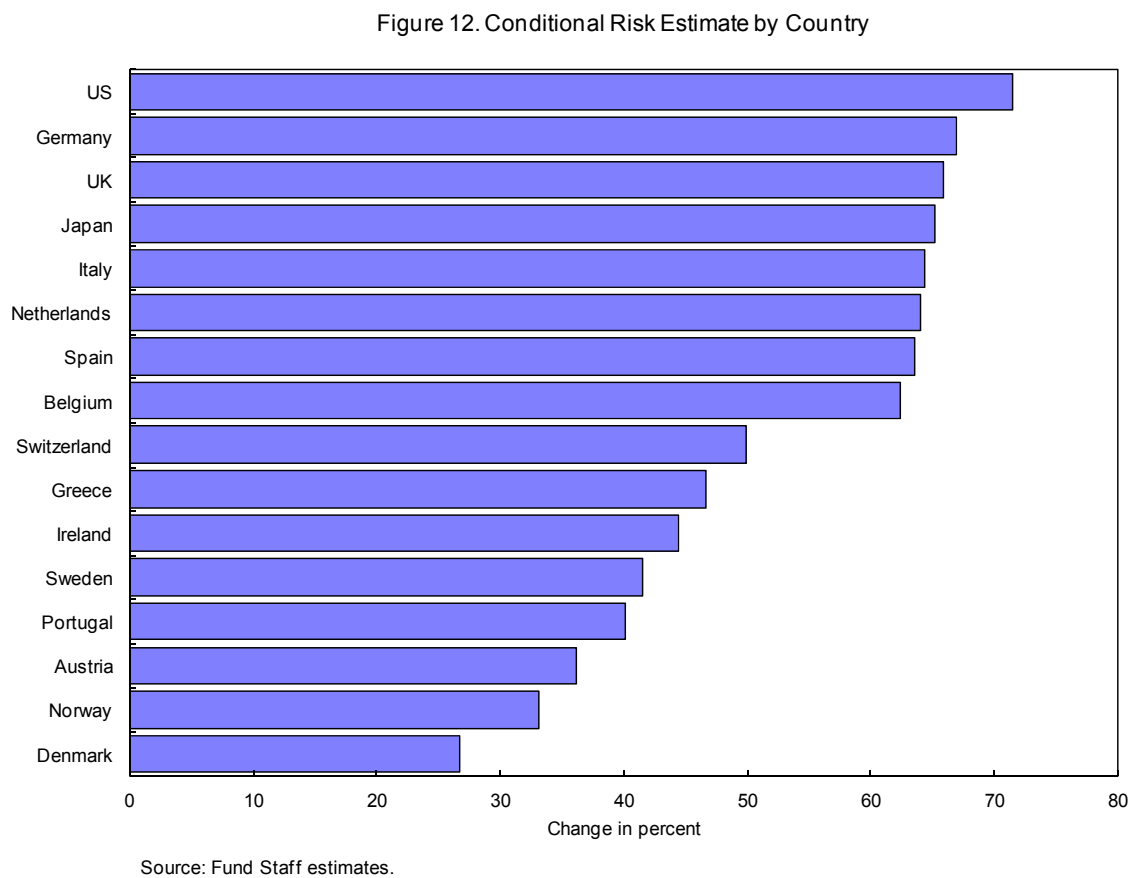


21. The results from quantifying risk from Greece, Ireland, Italy, Portugal, and Spain (EA5) are largely consistent with those from a detailed analysis of the French banks' direct exposure to the EA5. Based on the latest BIS data, French bank exposures account for about 7 percent of bank assets and 30 percent of nominal GDP. Of the French exposures to EA5 countries, 15 percent are to Greece, Ireland, and Portugal while 60 percent are to Italy and 25 percent to Spain. Exposures of French banks to EA5 countries are dominated by claims on nonfinancial corporates. The sector breakdown shows that about half of the exposures are accounted for by claims on corporates and a third are accounted for by holdings of government securities (Figure 13). The two French banks most exposed to Greece gain substantial exposures mostly through the loan books in their Greek subsidiaries, which are small in comparison with the size of the respective French parent banks. Individual French banks' exposures to Greece, Portugal, and Spain range from 2 to 10 percent of equity, compared with about 70 percent of large European banks having exposures above 10 percent of equity and the largest one having exposures of over several times of equity.

Figure 13. France: Banks' Exposure to EA5

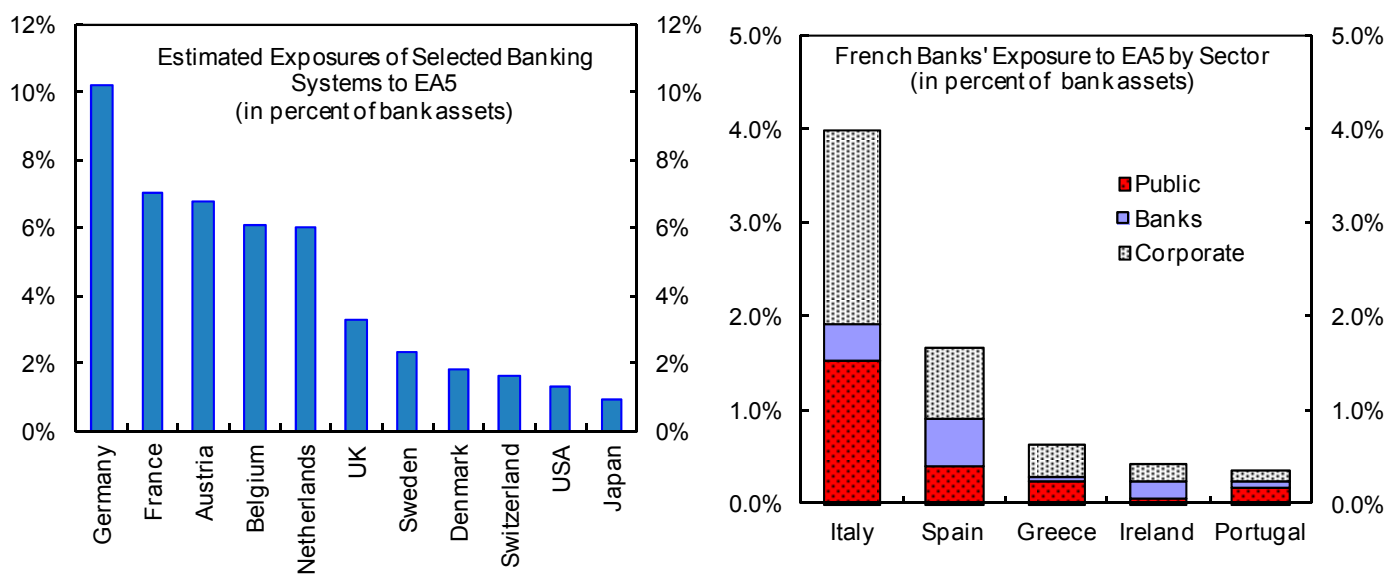

Sources: BIS, BdF, and Fund staff estimates.

\section{Conclusions}

\section{Some tentative findings emerge from the analysis of recent credit dynamics in} France and systemic linkages of major French banks with 41 large and complex financial institutions in 16 advanced countries. Evidence from the bank lending survey, the substitution between loan and bond markets, and the SMEs' access to finance suggests that the still low credit growth is more likely to be demand-driven. The CDS spreads of French banks under extreme stress based on quantile regressions show that their systemic linkages with large and complex financial institutions in other countries could lead to a pronounced increase, on average, in their riskiness. The wide distribution seems to indicate that depending on the strength of the linkages and sources of stress, it is about equally likely to have small and large changes of risks. In case of the large changes of risks, a negative impact on credit may take place, which would call for enhanced vigilance and proactive policies. 


\section{REFERENCES}

Adrian, Tobias, and Markus K. Brunnermeier, 2008, “CoVaR,” Staff Report No. 348 (New York: Federal Reserve Bank).

Banque de France, 2010, "Synthèse de l'évaluation des risques du système financier français (Financial Risk Assessement).

Bayoumi, T. and Melander, O. 2008, "Credit matters: empirical evidence on U.S. macrofinancial linkages”, IMF Working Paper 08/169.

Chan-Lau, Jorge A., 2010, Regulatory capital charges for too-connected-to-fail institutions: a practical proposal, IMF Working Paper 10/98(Washington: International Monetary Fund).

Collin-Dufresne, Pierre, Robert Goldstein, and J. Martin, 2001, The determinants of credit spread changes, Journal of Finance 56, 2177-2207.

Commission bancaire, 2010, Rapport de la Commission bancaire Pour L'année 2009.

De Bondt, Gabe, Angela Maddaloni, José-Luis Peydró, and Silvia Scopel, 2010, “The Euro Area Bank Lending Survey Matters: Empirical Evidence for Credit and Output Growth”, ECB Working Paper No. 1160.

Fama, Eugene, and Kenneth French, 1989, Business conditions and expected returns on stocks and bonds, Journal of Financial Economics 25, 23-49.

— 1993, Common risk factors in the returns on stocks and bonds, Journal of Financial Economics 33, 3-56.

Harjes, Thomas, 2010, "Is there a Bank Credit Crunch in the Euro Area?", Background material, IMF

International Monetary Fund, 2009a, World Economic Outlook, World Economic and Financial Surveys.

— 2009b, Global Financial Stability Report, World Economic and Financial Surveys

— 2010, World Economic Outlook, World Economic and Financial Surveys. 
International Monetary Fund (IMF)/Bank of International Settlements (BIS)/Financial Stability Board (FSB), 2009, "Guidance to Assess the Systemic Importance of Financial Institutions, Markets and Instruments: Initial Considerations."

Kashyap, Anil, Stein, Jeremy and David W. Wilcox, 1993, "Monetary Policy and Credit Conditions: Evidence from the Composition of External Finance," American Economic Review Vol. 83 (March) pp. 78-98.

Koenker, Roger, 2005, Quantile Regression, Econometric Society Monograph No. 38 (Cambridge, United Kingdom: Cambridge University Press).

— No. 1, pp. 33-50.

Lacroix, Renaud, and Jérémi Montornés, 2009, Analyse de la portée des résultats du Bank Lending Survey au regard des données de credit, Bulletin de la Banque de France No. 178.

Liebert, Christian, 2009, La Médiation du credit, Bulletin de la Banque de France No. 178.

Lepetit, Jean-François, 2010, "Rapport sur le risque systémique.”

Lown, C. and D.P. Morgan (2006), The credit cycle and the business cycles: new findings using the loan officer opinion survey, Journal of Money, Credit and Banking, 38, 6, $1575-1597$.

Oliner, Stephen and Glenn Rudebusch, 1996, "Monetary Policy and Credit Conditions: Evidence from the Composition of External Finance: Comment," American Economic Review Vol. 86 (March), pp. 300-309.

Xiao, Yingbin, 2008, "Financing and Risks of French Firms," IMF Selected Issues Paper 08/74 (Washington: International Monetary Fund).

, 2009, "French Banks Amid the Global Financial Crisis," IMF Working Paper 09/201(Washington: International Monetary Fund). 


\section{France: Lessons from Past Fiscal Consolidation Plans ${ }^{1}$}

\section{A. Introduction: A Long History of Deficits}

1. Over more than $\mathbf{3 0}$ years, France has incurred chronic fiscal deficits, and only a few attempts to revert this pattern were made. Of the total of four relatively sizeable consolidation plans ("Plan Barre" of 1976-80, "Virage de la rigueur" of 1983-86, ${ }^{2}$ the first five-year budgetary plan of 1994-97 prepared for the EMU accession process, and the Excessive Deficit Procedure of 2003-07 under the Stability and Growth Pact) this note will only focus on the two most recent ones. Earlier attempts were hampered by the absence of any budgetary planning that would span several years and resulted either in a quick reversal of the consolidation plan due to deteriorating macroeconomic conditions (the first attempt) or in a painful procyclical consolidation in which growth underperformance largely offset the structural consolidation effort (the second attempt).

France: Evolution of General Government Balance and Debt Ratios, 1970-10 (in percent of GDP)

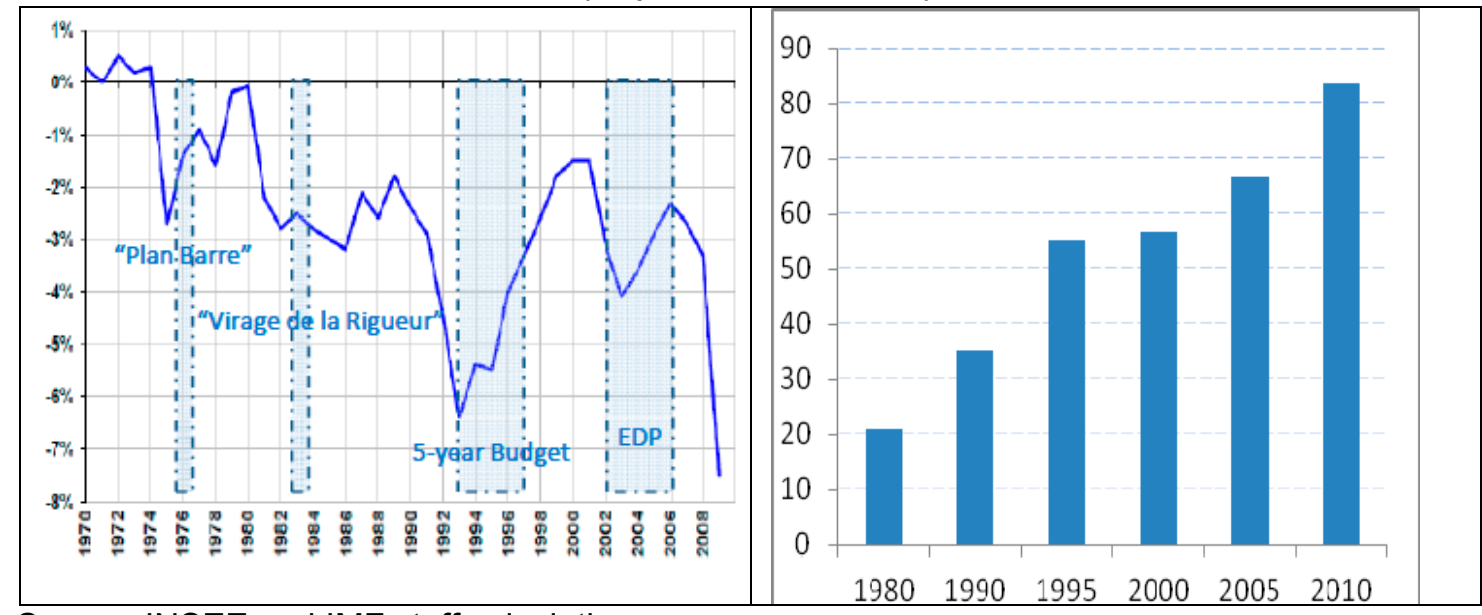

Source: INSEE and IMF staff calculations.

2. As compared to past fiscal consolidation episodes in other large economies, the French episodes exhibit similar patterns in terms of timing and achieving the announced objectives. Germany and the UK had similarly timed early consolidation

\footnotetext{
${ }^{1}$ Prepared by Edouard Martin, Irina Tytell, and Irina Yakadina. This note is part of a research project on past fiscal adjustment plans across countries conducted at the IMF's Fiscal Affairs Department. The authors thank seminar participants at the Ministère de l'Économie, de l'Industrie, et de l'Emploi and the IMF's Fiscal Affairs Department for valuable comments and Pierre Ecochard and Samuel De Lemos Peixoto of the European Commission's DG ECFIN for help with some of the data. Anastasia Guscina provided excellent research assistance.

${ }^{2}$ The focus of this consolidation episode was on reducing the current account deficit to regain competitiveness.
} 
France: History of Fiscal Consolidations : General Government Revenues and Expenditures (left axis, in percent of GDP) and Real Growth Rates (right axis), 1976-09
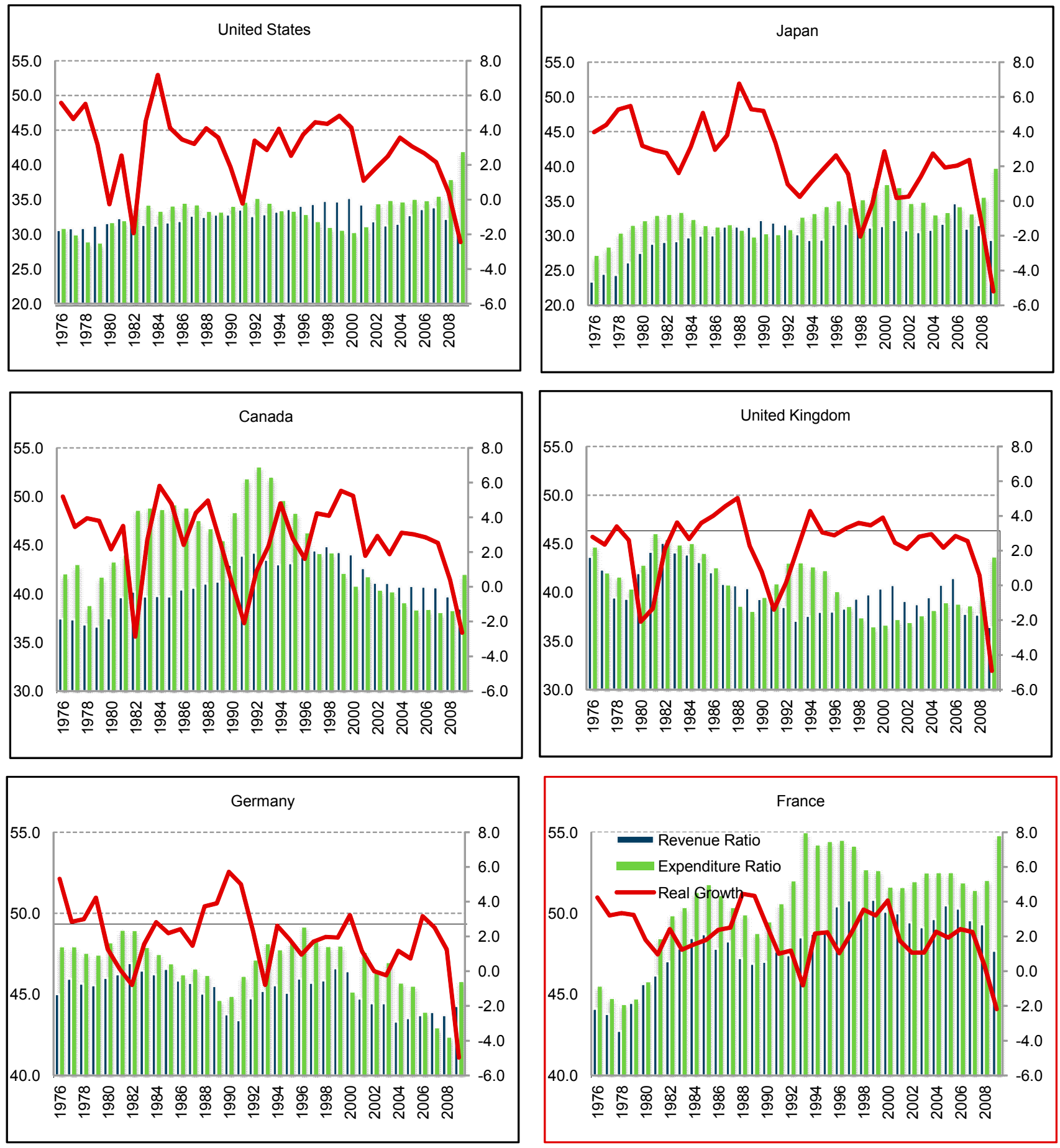

Source: WEO database, various national sources, and IMF staff calculations. 
episodes (1976-78, 1980-84 and 1980-86, respectively) but, unlike France, they relied on multiyear plans since the outset. The panel chart below illustrates the sizeable deterioration of the fiscal stance in each of the six large economies in the early 90s, as a consequence of the global economic recession. This triggered a global fiscal consolidation attempt that started with Germany and the UK (1992), continued with France and the US (1993), and was joined by Canada (1994). In Japan, the return to positive, but rather tepid, growth delayed the start of consolidation until 1997; meanwhile, the public debt kept accumulating.

\section{In France, each level of government contributed to the trend deterioration of}

public finances, yet for different reasons. Of the three levels of public administration, as of 2008 , central government spending accounted for about 38 percent of total spending, as compared to 42 percent for the social security administrations and 20 percent for local governments. For the latter, the well-contained deficits since the early 90s reflect the Golden Rule that restricts borrowing only to investment purposes (about one-quarter of expenditures). In fact, as a result of fiscal decentralization, further transfers of responsibilities, and additional sources of fiscal revenues, the share of the local government spending in GDP has doubled. The graph below highlights another French specificity, namely a sizeable correlation between the deficit patterns of the central government and the social security systems that have almost identical tax bases and are very sensitive to the cyclical conditions. Both the social security administrations and local governments have been operating under rather soft budget constraints over the period under consideration and have relied on ever increasing transfers of resources from the central government.

France: Fiscal Balance Trajectory by Subsector of the General Government, 1978-2008

(in percent of GDP)

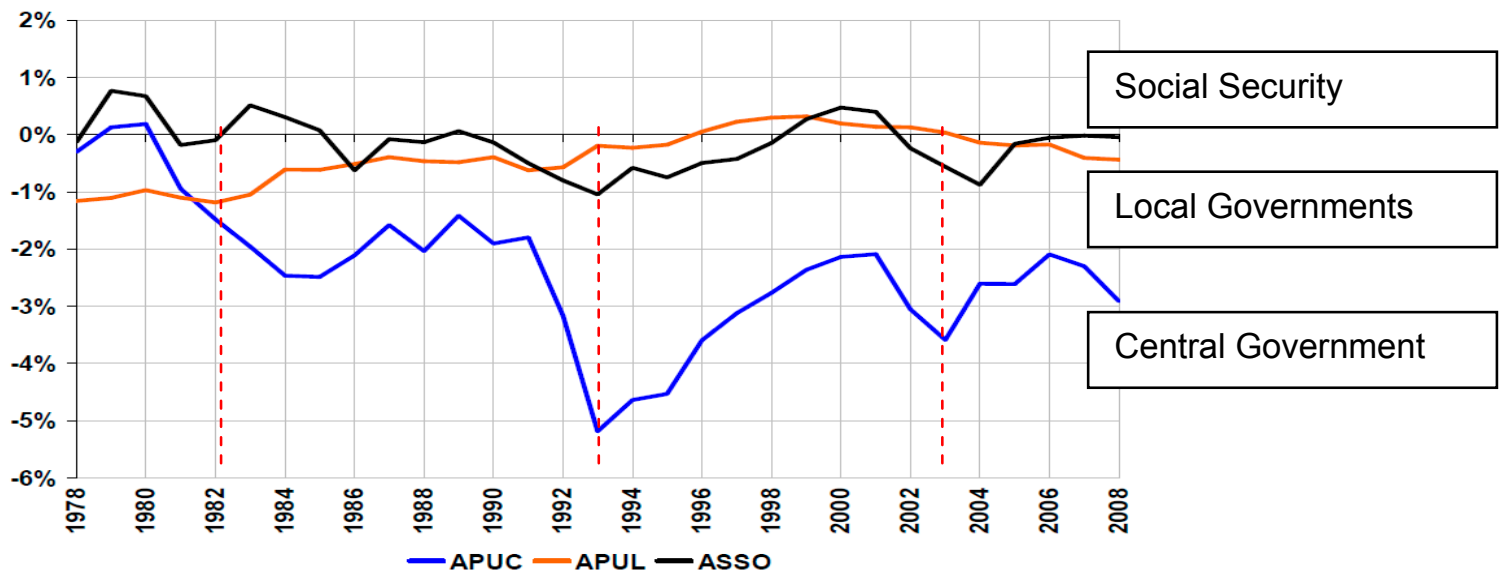

Source: INSEE. 


\section{Our main findings are in line with the existing literature on fiscal}

consolidations. ${ }^{3}$ Every consolidation attempt in France was triggered by: (i) a prior severe deterioration of fiscal ratios (marked by the dashed lines in the graph above); (ii) a potentially high reward from consolidation (or a high punishment for not achieving one) and hence, a strong political will; and (iii) a shared resolve for consolidation at all levels of government, including local governments and the social security administrations. The latter is best illustrated during the mid-90s episode, during which the central government's efforts were accompanied by a period of declines in real spending on healthcare (which accounts for over 8 percent of GDP, or about a third of the total social security spending in France, and contributes about half to its deficit). As soon as healthcare spending started to increase again (2000-04), this time due to a double shock from the hospital tariff adjustment and the introduction of the 35-hour work week, the gains from the previous consolidation were partly undone. The activation of the Excessive Deficit Procedure of 2003-07 entailed a subsequent reform of the healthcare system that, in turn, helped during the 2004-06 consolidation.

\section{B. A First Attempt at a Medium-term Consolidation in 1994-1997}

\section{The First Five-Year Budgetary Plan: The 1994 Reference Law for Public Finances}

5. In response to the deterioration of the fiscal situation in the early 1990s, the French authorities adopted in early 1994 a five-year reference law on public finance control ("Loi d'orientation quinquennale relative à la maîtrise des finances publiques"). This law, which constituted a first attempt at medium-term budgeting, set the stabilization, and then reduction, of government debt as the main goal of fiscal policy. Meeting this goal was expected to create additional fiscal space, avoid crowding-out of private investment, and allow France to meet the recently adopted Maastricht criteria (i.e. an overall deficit of less than 3 percent of GDP and a public debt of less 60 percent of GDP) by 1997, in order to become a member of the European Monetary Union (EMU). In that sense, the reference law can be viewed as an implementation tool of the convergence program presented jointly by France and Germany to the European Council in November 1993.

\section{In order to meet its overarching goal, the reference law set a number of} quantitative medium-term objectives. These included a central government deficit target of 2.5 percent of GDP by 1997 and a limit on overall spending growth that implied a $1 / 2$ percent per year reduction in real terms. In order to comply with the Maastricht criteria set for the general government, the law assumed a gradual improvement in the balances of local governments and social security administrations. Revenues (including privatization receipts)

\footnotetext{
${ }^{3}$ See Chapter IV of the OECD Economic Outlook 2007 and references therein.

${ }^{4}$ In this section, "central government" refers to the state ("État"), which is covered by the budget laws, and does not include the other central government units ("Organismes d'administration central.")
} 
were expected to grow at 2.8 percent per year over 1995-97, on average, in line with nominal GDP. Any additional revenues from better-than-expected macroeconomic developments were to be saved or used to finance a reduction of the tax burden. In addition, draft budget laws were to be accompanied by reports presenting a trajectory of five-year budgetary projections that targeted a deficit reduction by about 0.5 percent of GDP per year. The companion budget law for 1994 was consistent with these objectives and stipulated a reduction in the number of civil servants, wage moderation, a substantial decline in investment spending, and a deceleration in transfers to local governments, as well as a slight decline of the tax burden, owing primarily to a reform of personal income taxation, and a rise in privatization receipts.

\section{A Mixed Start: 1994-1995}

7. While the 1994 deficit ended up in line with the budgetary objectives, the underlying spending was significantly higher than planned. Contrary to what was envisaged under the five-year reference law, rather than saving the additional revenues resulting from higher-than-expected growth, these were used to finance a number of additional expenditure items, including increases in school start allowances, social spending, labor market measures, and peace-keeping operations.

8. In 1995, the cycle of ex-ante expenditure restraint and ex-post spending overruns continued. The budget law provided for a further decline in the deficit, to 3.5 percent of GDP (including privatization receipts), based primarily on expenditure restraint and increases in excises. However, the new government that was formed after the May 1995 presidential elections passed a supplementary budget providing for additional spending in support of employment, social housing, and small- and medium-sized enterprises. These new outlays, along with the spending overruns observed during the first half of the year, were to be financed through (temporary) increases in taxes and some savings on non-priority spending. The weakening of economic activity during the second half of the year, as well as spending overruns, necessitated the adoption of a second supplementary budget in November. At this time, extra expenditure cuts and the mobilization of nontax revenue allowed the government to meet its deficit target.

\section{Expenditure Restraint at Last: 1996-1997}

9. The 1996 budget law was accompanied by an updated medium-term budget plan, reiterating the deficit objectives and commitments to future expenditure restraint. This updated plan covered the period of 1996-99 and, in line with the original plan, aimed at a gradual reduction (of about $1 / 2$ percent a year) of the deficit from 4.1 percent of GDP 
(excluding privatization receipts) in 1995, to 3 percent in 1997 and 2 percent in 1999. ${ }^{5}$ Here too, the adjustment was to be achieved through keeping spending constant in real terms and maintaining the tax-to-GDP ratio unchanged.

\section{Contrary to previous years, expenditure restraint did actually happen in 1996.}

Consistent with the medium-term objectives, the 1996 budget law included a number of measures aimed at reining in expenditure growth, including a further decline in capital spending; a stability pact with local governments aimed at moderating central government transfers; the freezing of the pay scale of public sector employees; and cuts in defense spending and social transfers. Nevertheless, to meet the Maastricht criterion on the deficit, the authorities had to take some last-minute measures in 1997.

\section{Overall Performance}

\section{Although the authorities accomplished a significant consolidation, the central} government deficit was not reduced as planned. The deficit declined by 1.6 percent between 1993 and 1997, 0.4 percent less than initially planned. To meet the Maastricht deficit criterion in 1997, one-off payments from France Telecom amounting to 0.45 percent of GDP had to be mobilized. Over 1993-97, the underperformance primarily reflected higher-than-planned increases in primary spending of about 0.8 percent of GDP and lowerthan-expected economic growth (which contributed to an increase in the deficit-to-GDP ratio of 0.2 percent) that were only partly offset by an increase in the tax burden, which helped to reduce the deficit by 0.5 percent of GDP. As a result of higher deficits and lower growth, the debt-to-GDP ratio increased more than planned, to 44 percent of GDP instead of 42 percent in 1997.

\section{This fiscal consolidation episode illustrated the institutional limits to the first} attempt at medium-term budgeting. The fact that the quantitative objectives of the reference law were not legally binding allowed for considerable discretion in the conduct of fiscal policy, as long as the overall deficit stayed on a declining path. In particular, in the absence of binding limits on spending growth, the government did not implement the expenditure restraint that it had committed to, especially when revenues were higher than envisaged.

\footnotetext{
${ }^{5}$ Contrary to the initial plan, which recorded privatization receipts in revenue above the line, the updated plan, in line with the Maastricht definition, recorded privatization receipts as part of financing.
} 
The 1994-97 Consolidation: Targets and Outcomes
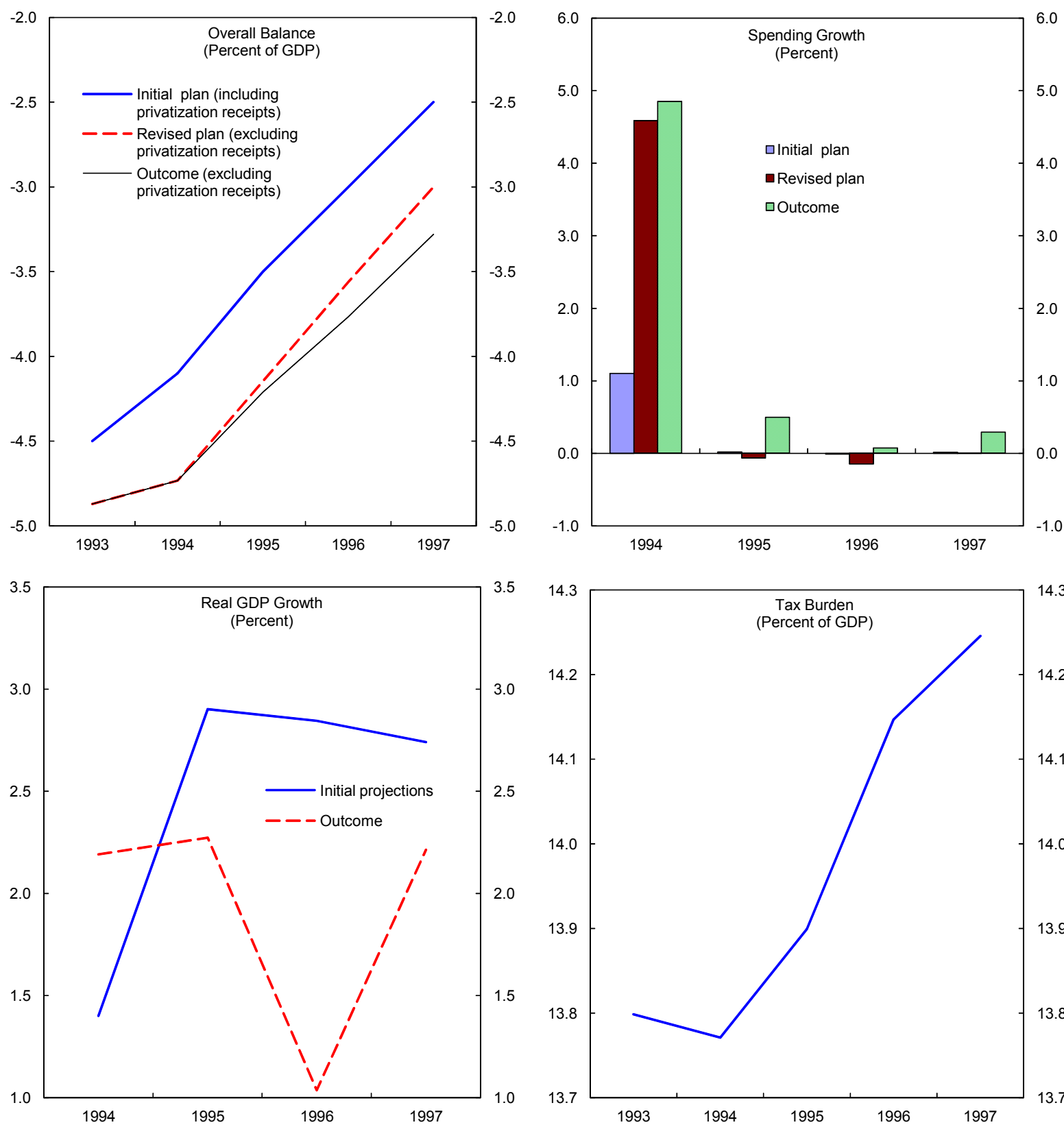

Source: WEO database, national sources, and IMF staff calculations 


\section{A More Systematic Approach to Medium-Term Budgeting: Consolidation Experiences Under the SGP}

\section{Overview}

13. France issued twelve annual stability programs (SPs) over 1998-2009, of which six envisaged reductions in the overall fiscal deficit of more than $1 / 2$ percent of GDP per year, all in the context of excessive deficit procedures (EDP). The first episode of a significant planned consolidation included five SPs submitted from 2003 to 2007 that aimed to reduce the deficit below 3 percent of GDP and terminate the EDP that lasted from June 2003 to January 2007. The second episode is ongoing and includes the most recent SP submitted in January 2010 that targets a large reduction in the overall fiscal deficit under the EDP opened in February 2009. Both planned consolidation episodes followed economic downturns and significant deteriorations in public finances.

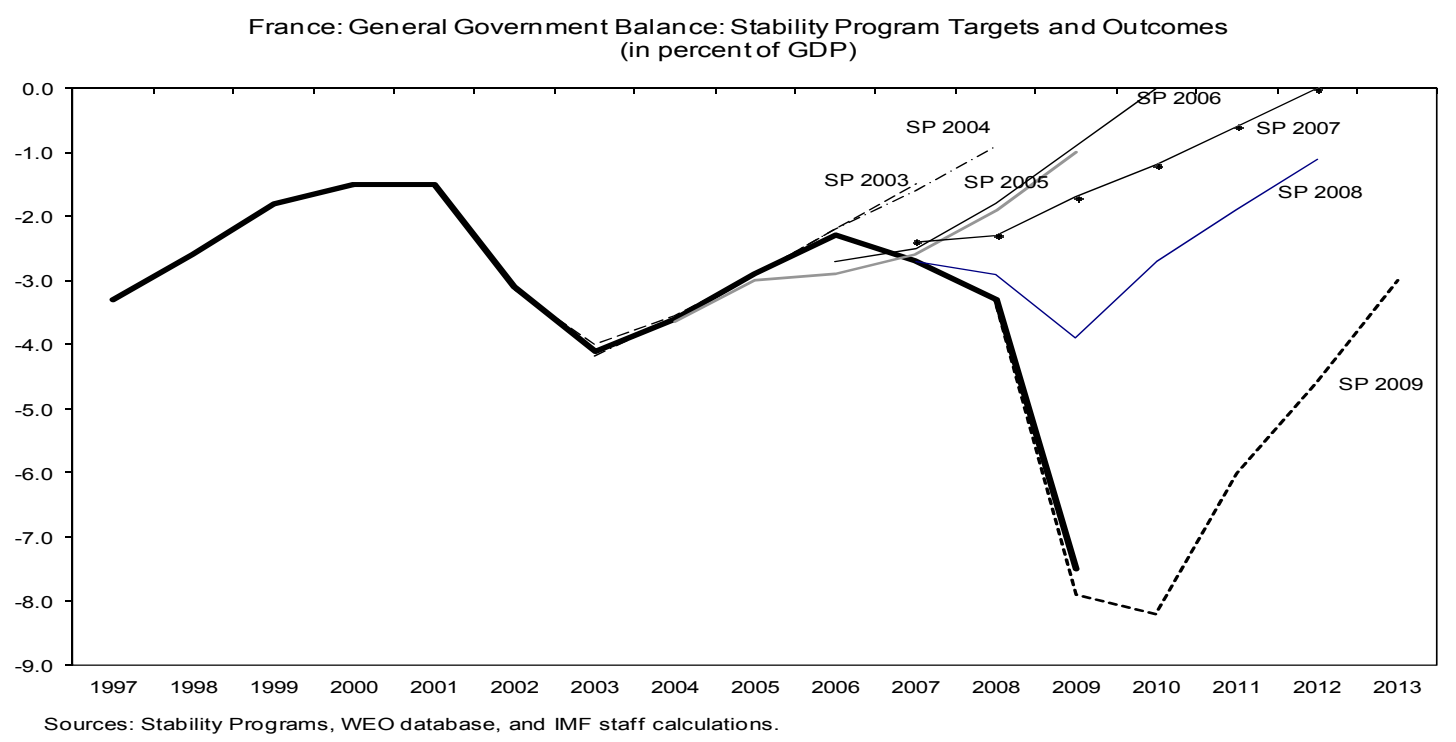

14. While deficit targets set in the successive SPs have been frequently missed, France succeeded in reducing the deficit below 3 percent of GDP and therefore terminating the first EDP. ${ }^{6}$ That said, the deficit dipped only slightly below 3 percent of

France: General Government Balance: Targets and Outcomes

\begin{tabular}{lcccccr}
\hline \multicolumn{7}{c}{} \\
\hline Actual & 2004 & 2005 & 2006 & 2007 & 2008 & 2009 \\
\hline SP 2003 & -3.6 & -2.9 & -2.3 & -2.7 & -3.3 & -7.5 \\
SP 2004 & -3.6 & -2.9 & -2.2 & -1.5 & & \\
SP 2005 & & -2.9 & -2.2 & -1.6 & -0.9 & \\
SP 2006 & & -2.9 & -2.6 & -1.9 & -1.0 \\
SP 2007 & & & -2.5 & -1.8 & -0.9 \\
SP 2008 & & & & -2.3 & -1.7 \\
Sources: Stability Programs, WEO database. &
\end{tabular}

\footnotetext{
${ }^{6}$ Notably, stability program targets have been frequently missed in many countries under the SGP (see Moulin and Wierts, 2006 and European Commission, 2007).
} 
GDP in 2005 thanks, in part, to a number of one-off receipts. It then remained just below the SGP ceiling during the global economic boom of 2005-07, before exceeding it again when the recent global recession put public finances under severe pressure.

\section{The Composition of Adjustment}

15. French SPs have focused on expenditure control, while revenue ratios have been targeted to remain stable or decline slightly. During the 2003-07 EDP, key adjustment measures included a legally binding zero real growth rule for central government spending, as well as significant health and pension reforms. Overall, the SPs of 2003-04 targeted reductions of the deficit by $0.6-0.7$ percent of GDP per year, on average, under the reference macroeconomic scenario, while the SPs of 2005-07 included a medium term objective (MTO) of balancing the budget.

\section{The deficit targets were attained, in part, thanks to favorable macroeconomic} developments over 2003-07. To assess the relative contributions of macroeconomic developments and fiscal effort to the overall performance, implementation discrepancies relative to SP targets are decomposed into parts corresponding to cyclically-adjusted revenues and primary expenditures, interest spending, and cyclical balances. This decomposition

\section{A Method of Decomposing Implementation Discrepancies}

Implementation discrepancies relative to SP targets are decomposed into components corresponding to cyclically-adjusted revenues and primary expenditures, interest spending, and cyclical balances, as follows:

$$
\begin{aligned}
\left(b_{t}^{A}-b_{t}^{T}\right)=\left(r_{t}^{A}-r_{t}^{T}\right)-\left(g_{t}^{A}-g_{t}^{T}\right)-\left(i_{t}^{A}-i_{t}^{T}\right) \\
=\left[\left(r_{t}^{A, S}-r_{t}^{T, S}\right)-\left(g_{t}^{A, S}-g_{t}^{T, S}\right)\right]+\left[\left(r_{t}^{A, C}-r_{t}^{T, C}\right)-\left(g_{t}^{A, C}-g_{t}^{T, C}\right)\right]-\left(i_{t}^{A}-i_{t}^{T}\right),
\end{aligned}
$$

where $b, r, g$, and $i$ stand, respectively, for the overall balance, revenues, primary expenditures, and interest spending (all relative to GDP), superscripts refer to actual $(A)$, target $(T)$, cyclical $(C)$, and cyclically-adjusted $(S)$, and subscripts denote years. Cyclically-adjusted revenues and primary expenditures are expressed as: ${ }^{1}$

$$
\begin{gathered}
\left(r_{t}^{A, S}-r_{t}^{T, S}\right)=\left[r_{t}^{A}\left(1-g a p^{A}\right)^{\varepsilon_{r}}-r_{t}^{T}\left(1-g a p^{T}\right)^{\varepsilon_{r}}\right] \cong\left[r_{t}^{A}\left(1-\varepsilon_{r} g a p^{A}\right)-r_{t}^{T}\left(1-\varepsilon_{r} g a p^{T}\right)\right] \\
\left(g_{t}^{A, S}-g_{t}^{T, S}\right)=\left[g_{t}^{A}\left(1-g a p^{A}\right)^{\varepsilon_{g}}-g_{t}^{T}\left(1-g a p^{T}\right)^{\varepsilon_{g}}\right] \cong\left[g_{t}^{A}\left(1-\varepsilon_{g} g a p^{A}\right)-g_{t}^{T}\left(1-\varepsilon_{g} g a p^{T}\right)\right]
\end{gathered}
$$

where $g_{a p}{ }^{A}=\frac{Y^{A}-Y^{*}}{Y^{A}}$ and $g a p^{T}=\frac{Y^{T}-Y^{*}}{Y^{T}}$ refer to, respectively, actual and target output gaps relative to GDP (assuming away any forecast errors in potential output $Y^{*}$ ), while $\varepsilon_{\mathrm{r}}$ and $\varepsilon_{\mathrm{g}}$ denote elasticities of revenue and primary expenditure, respectively. For France, the revenue elasticity is set at 1.0 and the primary expenditure elasticity is set at -0.1 , in line with recent estimates by the OECD and the European Commission. ${ }^{2}$

${ }^{1}$ See Fedelino, Ivanova, and Horton (2009) for a description of the cyclical adjustment methodology.

${ }^{2}$ See European Commission (2005) and Girouard and André (2005). 
France: General Government Implementation Discrepancies: Actual - Target, 2004-09 (in percent of GDP)
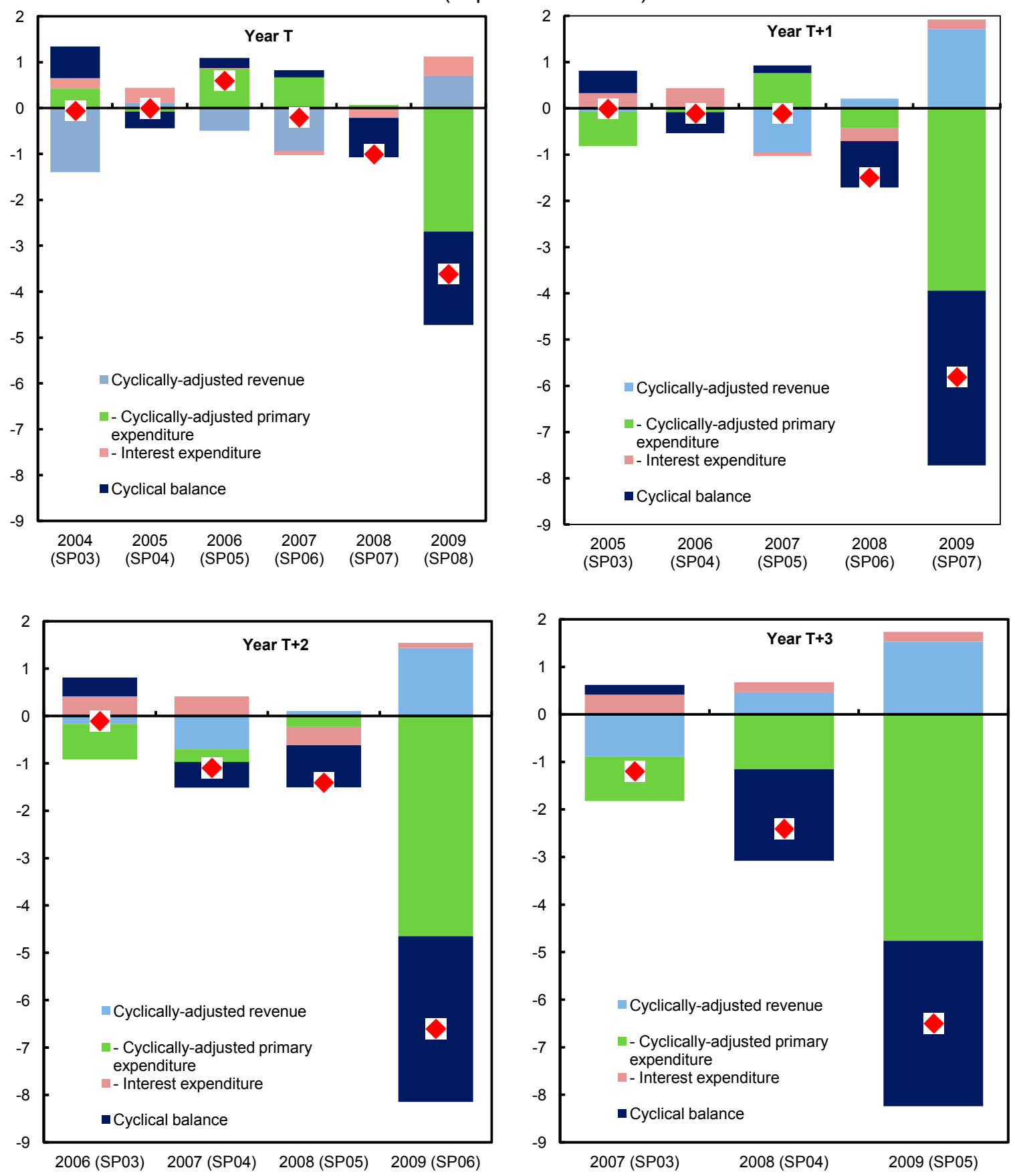

Source: Stability Programs, WEO database, and IMF staff calculations. 
shows that over 2003-07 cyclical balances often exceeded expectations thanks to strong GDP growth, while interest spending was typically below targets owing to low interest rates. Over the same period, cyclically-adjusted revenues tended to fall short of targets, while cyclically-adjusted expenditures were sometimes lower than targets (although not in the outer years of the SPs). In sum, favorable macroeconomic developments helped offset revenue shortfalls and expenditure slippages relative to SP targets in the outer years during this consolidation episode. Once the recent global recession set in, cyclical balances fell sharply below expectations, while primary expenditures rose significantly above targets, reflecting both automatic stabilizers and discretionary stimulus measures. ${ }^{7}$

\section{A Closer Look at Macroeconomic Assumptions}

\section{French SPs have not relied on conservative growth assumptions, but they}

benefitted from the favorable macroeconomic environment over 2003-07. ${ }^{8}$ The SPs have typically included two scenarios: a cautious, or low, (reference) scenario with real GDP growth of $2 \frac{1}{4}-2 \frac{1}{2}$ percent per year and a favorable, or high, scenario with real GDP growth of 3 percent per year. Even the cautious (reference) scenario has tended to be somewhat optimistic in comparison with consensus forecasts $(\mathrm{CF})$ published just a couple of months before the SPs and covering similar time horizons. However, as the consolidation under the 2003-07 EDP took place in a period of global economic boom and relatively high growth

\begin{tabular}{|c|c|c|c|c|c|c|}
\hline & 2004 & 2005 & 2006 & 2007 & 2008 & 2009 \\
\hline Actual & 2.3 & 1.9 & 2.4 & 2.3 & 0.1 & -2.5 \\
\hline CF 2003 & 1.6 & 2.4 & 2.6 & 2.5 & & \\
\hline SP 2003 & 1.7 & 2.5 & 2.5 & 2.5 & & \\
\hline CF 2004 & & 2.2 & 2.2 & 2.3 & 2.3 & \\
\hline SP 2004 & & 2.5 & 2.5 & 2.5 & 2.5 & \\
\hline CF 2005 & & & 1.8 & 2.1 & 2.1 & 2.1 \\
\hline SP 2005 & & & 2.3 & 2.3 & 2.3 & 2.3 \\
\hline CF 2006 & & & & 2.0 & 2.0 & 2.1 \\
\hline SP 2006 & & & & 2.3 & 2.3 & 2.3 \\
\hline CF 2007 & & & & & 1.9 & 2.1 \\
\hline SP 2007 & & & & & 2.3 & 2.5 \\
\hline CF 2008 & & & & & & 0.5 \\
\hline SP 2008 & & & & & & 0.4 \\
\hline
\end{tabular}
rates in France, the SP projections during that time turned out close to actual growth rates.

\section{A Closer Look at Spending by Levels of Government}

\section{Real spending growth has tended to overrun SP targets, often reflecting} slippages by local governments and social security systems. The French SPs have targeted average annual real spending growth at all government levels, including the general government (GG), the central government (CG), ${ }^{9}$ the local governments (LG), and the social

\footnotetext{
${ }^{7}$ Notably, this analysis does not take into account the effect of the past recession on the revenue elasticity.

${ }^{8}$ Optimistic biases in growth assumptions that underlie fiscal projections have been identified in a number of countries under the SGP (see Jonung and Larch, 2004 and Strauch, Hallerberg, and von Hagen, 2004).

${ }^{9}$ The central government is defined to include the State but not central government agencies.
} 
security systems (SS). The general government real spending growth has typically exceeded targets, with overruns often reflecting slippages by local governments and social security systems, which account for about 20 percent and 45 percent of total expenditures, respectively. The central government-bound by the zero real spending growth rule - managed to reduce its France: Real Spending Growth by Levels of Government: Targets and Outcomes (in percent)

\begin{tabular}{lcccc}
\hline & GG & CG & LG & SS \\
\hline SP2003 Targets & 1.1 & 0.0 & 2.0 & 1.7 \\
SP2003 Outcomes & 2.2 & -1.5 & 4.3 & 2.6 \\
SP2004 Targets & 1.2 & 0.0 & 1.8 & 1.7 \\
SP2004 Outcomes & 1.7 & -1.9 & 3.6 & 1.8 \\
SP2005 Targets & 0.6 & -1.3 & 0.5 & 0.9 \\
SP2005 Outcomes & 2.4 & 0.7 & 3.3 & 2.8 \\
SP2006 Targets & 0.6 & -1.5 & 2.0 & 1.1 \\
SP2006 Outcomes & 2.3 & 2.1 & 2.2 & 2.4 \\
SP2007 Targets & 1.1 & 0.0 & 1.4 & 1.9 \\
SP2007 Outcomes & 3.7 & 4.1 & 2.9 & 4.5 \\
SP2008 Targets & 1.3 & 0.0 & 1.3 & 1.8 \\
SP2008 Outcomes & 3.7 & 4.1 & 2.9 & 4.5 \\
Sources: Stability Programs, WEO database, and IMF staff calculations. & & &
\end{tabular}
spending in real terms over the course of SP2003 and SP2004, on average. ${ }^{10}$

19. Strong GDP growth over 2003-07 helped offset spending overruns. Although the real spending growth of the general government has tended to exceed SP targets, it remained close to the real GDP growth from 2004 to 2007 and even dipped below it in $2006 .^{11}$ Therefore, favorable macroeconomic conditions during the global economic boom that preceded the recent recession helped contain expenditure ratios.

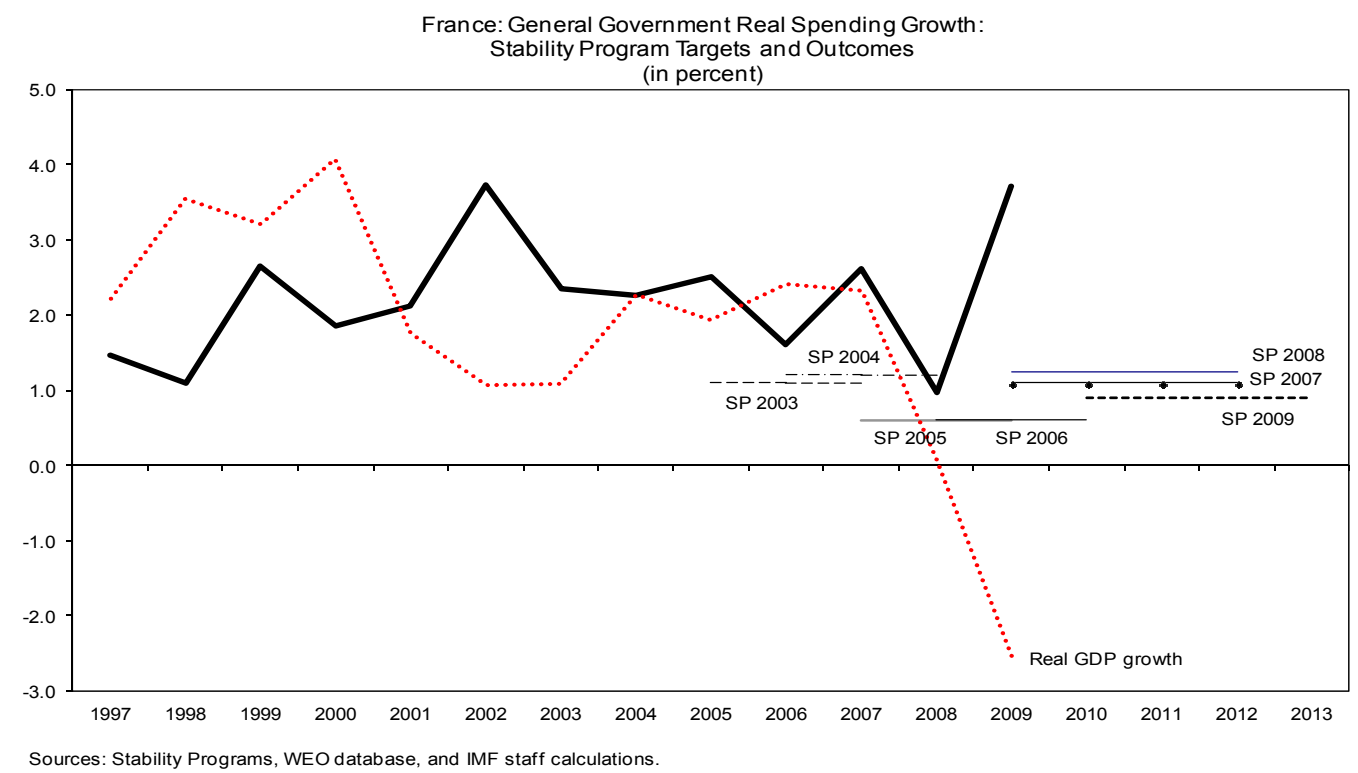

\footnotetext{
${ }^{10}$ The average annual real spending growth targets have been set for years $\mathrm{T}+1$ to $\mathrm{T}+3$ in most past SPs. The outcomes are computed for the corresponding years through 2009. Inter-governmental transfers are excluded from this analysis.

${ }^{11}$ The real spending growth is obtained from nominal expenditures using CPI minus tobacco as a deflator.
} 


\section{Conclusions}

20. Past episodes of fiscal consolidation highlight the importance of having both a realistic assessment of how much effort would be required and strong motivation to achieve the target. The former was, on the one hand, facilitated by a multi-year approach but, on the other hand, put at risk by somewhat sanguine macroeconomic assumptions. Compared to the period of global economic boom previous to the recent recession, the need for realistic macroeconomic assumptions is more acute at a time when economic growth is fragile. The realism of macroeconomic forecasts could be enhanced if they were to be prepared or validated by an independent body. Another crucial element of a successful consolidation is political resolve to set binding spending limits for each level of government within the multi-year budget framework. Strong peer and market pressure can help bolster such political determination. To ensure the credibility of political commitment, consolidation strategies could be cemented into a formal fiscal rule across all levels of government. Together, credible political commitment and realistic macroeconomic assumptions would help to ensure sustainable public finances in France. 


\section{REFERENCES}

Champsaur, P. and J. P. Cotis, 2010, "Rapport Sur La Situation Des Finances Publiques", report, available at lesrapports.ladocumentationfrancaise.fr/BRP/104000234/0000.pdf.

Cotis, J. P., 2007, "Fiscal Consolidation: Lessons from Past Experience", Chapter IV of the OECD Economic Outlook, May, 2007

European Commission, 2005, "New and Updated Budgetary Sensitivities for the EU Budgetary Surveillance", Information Note for the Economic and Policy Committee, DG ECFIN, September.

European Commission, 2007, "How to Stick to Medium-Term Budgetary Plans", Part III of Public Finances in EMU 2007, European Economy No. 3/2007, DG ECFIN, pp. 149192.

Fedelino, A., A. Ivanova, and M. Horton, 2009, "Computing Cyclically-Adjusted Balances and Automatic Stabilizers", IMF Technical Notes and Manuals 09/05, Fiscal Affairs Department, May.

Girouard, N., and C. André, 2005, "Measuring Cyclically-Adjusted Budget Balances for OECD Countries", OECD Working Paper No. 434, Economics Department, July.

Jonung, L., and M. Larch, 2004, "Improving Fiscal Policy in the EU: The Case for Independent Forecasts", European Commission Economic Paper No. 210, DG ECFIN, July.

Moulin, L. and P. Wierts, 2006, "How Credible are Multiannual Budgetary Plans in the EU?", proceedings of the Banca d'Italia workshop on fiscal indicators, 30 March to 1 April.

Strauch, R., M. Hallerberg, and J. von Hagen, 2004, "Budgetary Forecasts in Europe - The Track Record of Stability and Convergence Programmes", European Central Bank Working Paper No. 307, February. 


\section{DeVelopments in France's EXternal Competitiveness-An UPdATE ${ }^{1}$}

This note reviews developments in France's external competitiveness and discusses the evolution of its export performance, including after the 2008 financial crisis. In the first part, the note finds that - consistent with many previous studies-France has been losing export market shares. Specifically, while France remains more competitive than some other key Euro Area economies - such as Italy and Spain - it has been outperformed by Germany. Furthermore-like other advanced economies-France has been losing competitiveness to emerging economies. In the second part, the note shows that France's export developments during the recovery have largely reflected the evolution of demand from its trading partners, with the real exchange rate having played a secondary role.

\section{A. Introduction}

1. Like many other countries, France's exports tumbled after the 2008 financial crisis. Total French exports lost over one third of its value in 2009:Q1 relative to the peak levels in 2008 before rebounding subsequently. Meanwhile, over a longer horizon - as indicated in many other previous studies such as Kierzenkowski (2009) as well as Kabundi and Nadal De Simone (2009)—France is losing competitiveness and export market share.

\section{This note seeks to revisit France's competitiveness and discuss the evolution of} France's export performance during the financial crisis and subsequent recovery. With regard to the longer trend, the first part of the note compares the country's competitiveness with its European peers as well as emerging and developing economies. In the second part, the note aims to econometrically assess the contributions of the traditional determinants of trade to the short-term evolution of exports in the aftermath of the financial crisis as well as shed light on the effect of euro depreciation on exports.

3. The rest of the paper proceeds as follows: Section B presents some stylized facts in relation to France's export performance; Section C examines France's changes in export market share — both by regions and by products_-aiming to shed light on developments of France's competitiveness against the backdrop of the crisis and recovery; Section D quantifies the dynamic contributions of price competitiveness and foreign demand to exports using an error-correction model; finally, Section E concludes with policy implications.

\footnotetext{
${ }^{1}$ This note was prepared by Kevin C. Cheng.
} 


\section{B. Stylized Facts}

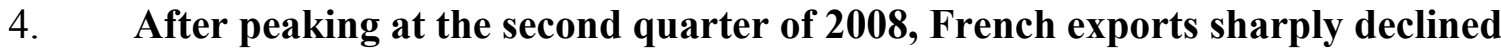
following the financial crisis and then gradually recovered after bottoming out in 2009:Q1.

From the peak to the trough, French exports lost over one third of its value in US dollar terms, with the decline in exports to Euro Area and non-Euro Area roughly of equal magnitude (Figure 1). The decline in volume, however, is much less pronounced, partly reflecting of the impact of euro-dollar exchange rate movements on export valuation.

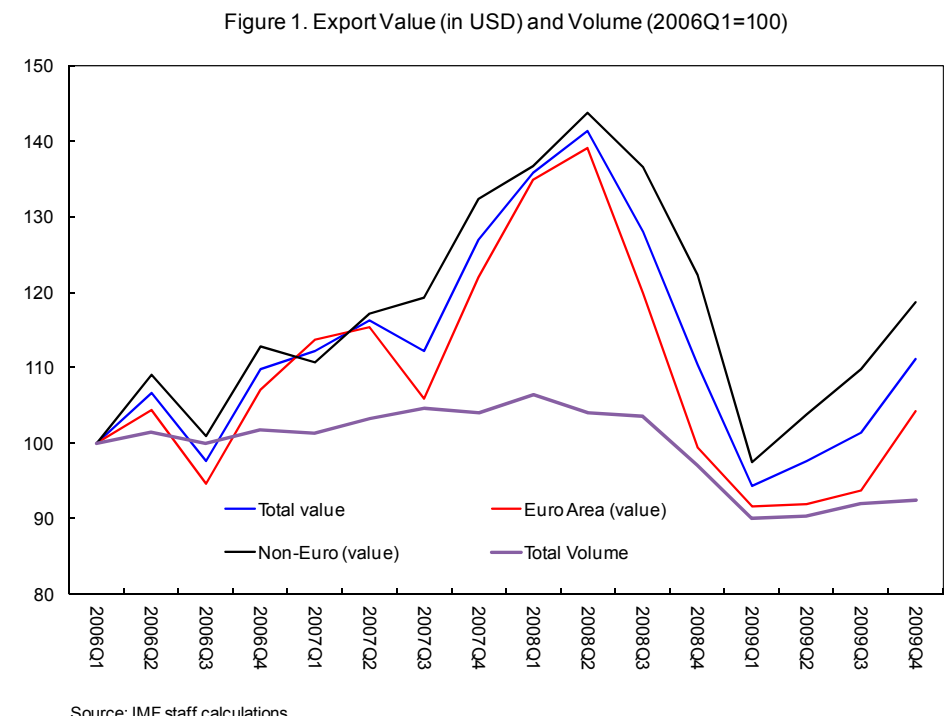

5. The impact on GDP growth, however, has been more moderate than in many other European economies (Table 1). This partly reflects France's smaller degree of trade openness. In fact, the contribution of exports to GDP growth has been relatively small, averaging to around one percent per annum during 2000-07-roughly one third of that in Germany and half of the Euro Area average. Consequently, the impact of the drop in international trade associated with the financial crisis took a smaller toll on the overall economy compared to its European peers, averaging to around negative 2.7 percent of GDP during 2008:Q3-2009:Q2 on a year-on-year basis, approximately half of the impact that Germany suffered during the same period. Conversely, the subsequent normalization of world trade also plays a relatively smaller role in France's recovery.

Table 1. Contributions of Exports to Real GDP Growth (year-on-year growth, in percent)

\begin{tabular}{lccccccccc}
\hline & $2000-07$ & $2008: Q 1$ & $2008: Q 2$ & $2008: Q 3$ & $2008: Q 4$ & $2009: Q 1$ & 2009:Q2 & 2009:Q3 & 2009:Q4 \\
\hline France & 1.0 & 1.5 & 0.2 & -0.3 & -2.0 & -4.7 & -3.9 & -3.3 & -1.3 \\
Germany & 3.1 & 3.6 & 2.7 & 1.7 & -3.2 & -8.9 & -9.4 & -7.9 & -2.6 \\
Italy & 0.9 & 0.0 & -0.1 & -1.1 & -3.4 & -6.5 & -6.6 & -5.2 & -3.0 \\
Spain & 1.5 & 1.2 & 0.8 & -0.9 & -2.2 & -5.3 & -4.6 & -3.3 & -0.9 \\
Euro Area & 2.3 & 2.5 & 1.7 & 0.5 & -3.2 & -7.4 & -7.6 & -6.0 & -2.0 \\
\hline
\end{tabular}

Sources: WEO 
6. Over a longer time span, the growth of France's exports has significantly lagged behind those of other major economies (Figure 2). Between 2000-04 and 2005-09, French exports of goods and service grew by 1.9 percent on an annualized basis, compared with 6.6 percent for Germany and 4.2 percent for the Euro Area during the same time frame. The difference is even more pronounced when comparing France's export performance to that of emerging and developing economies, whose growth rate was almost five times that of France.

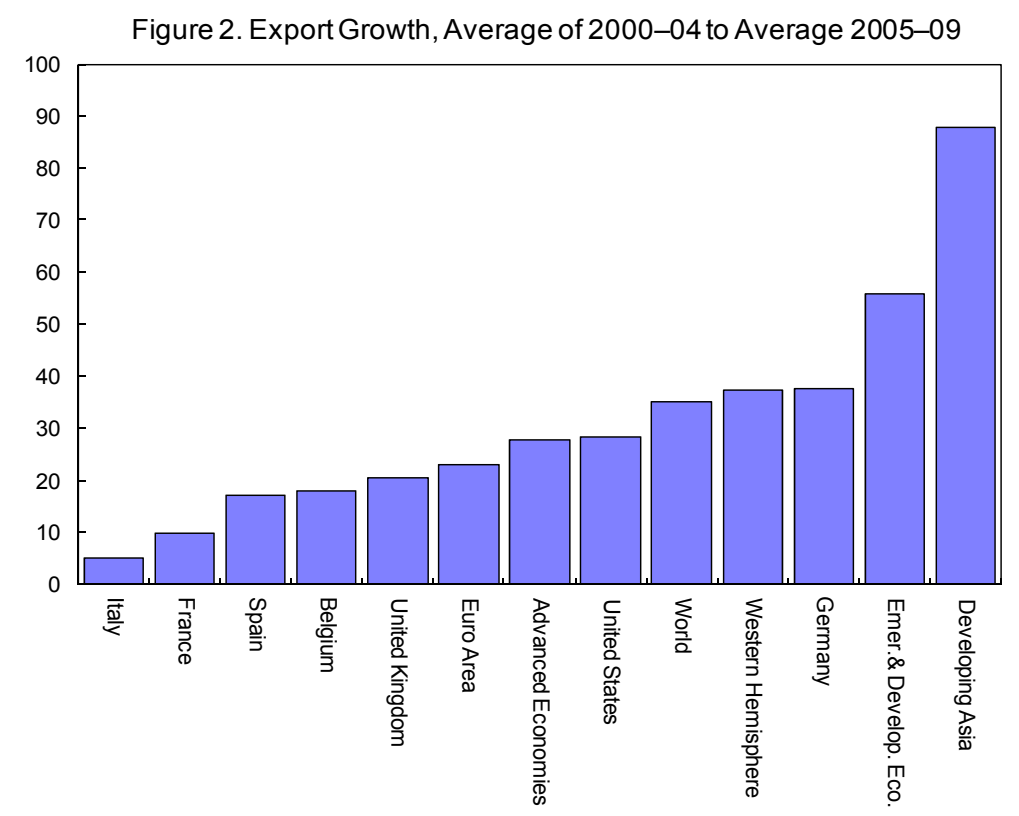

\section{The composition of France's export destinations has been relatively stable over} the past two decades, although there is some sign of a shift towards emerging economies after the crisis. France's exports have been primarily geared towards advanced economies, which account for over three quarters of the French exports during 2000-09. Among advanced economies, the Euro Area is France's principal export destinations, with half of the French exports designated for its euro partners. Exports to emerging and developing economies have gained importance towards the end of the 2000s - in part due to the faster recovery of emerging markets in the aftermath of the 2008 crisis — especially to developing Asia and the Middle East, although these continue to account for a relatively small share of total French exports.

Table 2. France's Main Export Destinations (In percent of France's total exports of goods and services)

\begin{tabular}{cccccc}
\hline & $1980-1989$ & $1990-1999$ & $2000-2009$ & 2008 & 2009 \\
Exports to Advanced Economies & 72 & 79 & 77 & 74 & 73 \\
Exports to Euro Area (aggreg.) & 38 & 45 & 50 & 50 & 49 \\
Germany & 15 & 17 & 15 & 16 & 16 \\
Italy & 11 & 10 & 9 & 9 & 8 \\
Spain & 4 & 7 & 9 & 8 & 8 \\
United Kingdom & 8 & 9 & 9 & 8 & 7 \\
United States & 6 & 7 & 7 & 6 & 6 \\
Emering \& Developing Economies & 24 & 18 & 21 & 24 & 25 \\
Africa & 9 & 6 & 5 & 6 & 6 \\
Developing Asia & 2 & 3 & 4 & 4 & 5 \\
Emerging Europe & 4 & 3 & 6 & 8 & 7 \\
Middle East & 5 & 3 & 3 & 3 & 4 \\
Western Hemisphere & 3 & 3 & 3 & 3 & 2 \\
\hline
\end{tabular}

Source: IMF staff calculations. 


\section{Is France Losing its Competitiveness?}

\section{With sluggish export growth, French exports have been gradually losing market} shares over the past few decades, although they have somewhat stabilized in recent years. Compared with the past decade, France has lost around $1 \frac{1}{2}$ percentage points of world export market share. But the decline in export market share is not unique to France, and appears to have been a negative shock common to most advanced economies, which have lost ten percentage points of market share altogether to emerging economies over the past decade. Nevertheless, the extent of France's loss appears to be more severe than for its peers in the Euro Area, which has collectively lost around 3.3 percentage points of global export market share, despite a much higher base. In particular, Germany - the largest exporter of the Euro Area-has only lost around $1 / 2$ percentage point of market share (Table 3 ). After the financial crisis, France export market share has picked up slightly.

Table 3. France's Export Market Shares (as a percent of total world imports, in value)

\begin{tabular}{lccccccc}
\hline & $1980-1989$ & $1990-1999$ & $2000-2009$ & 2006 & 2007 & 2008 & 2009 \\
\hline France & 6.0 & 5.8 & 4.4 & 4.2 & 4.1 & 4.0 & 4.1 \\
Belgium & 2.9 & 3.0 & 2.5 & 2.3 & 2.4 & 2.4 & 2.5 \\
Germany & 9.8 & 9.5 & 9.0 & 9.1 & 9.4 & 8.9 & 8.8 \\
Italy & 5.9 & 5.0 & 3.6 & 3.5 & 3.6 & 3.4 & 3.3 \\
Netherlands & 3.7 & 3.7 & 3.3 & 3.3 & 3.3 & 3.3 & 3.4 \\
Spain & 1.6 & 2.2 & 2.3 & 2.2 & 2.3 & 2.2 & 2.3 \\
Euro Area & 33.1 & 33.5 & 30.2 & 29.7 & 30.4 & 29.2 & 29.5 \\
United Kingdom & 5.6 & 5.5 & 4.6 & 4.8 & 4.4 & 4.0 & 4.0 \\
Advanced Economies & 76.0 & 80.3 & 70.6 & 69.3 & 68.7 & 66.4 & 67.5 \\
Emer.\& Develop. Eco. & 23.5 & 20.6 & 30.8 & 32.6 & 33.7 & 35.7 & 34.9 \\
\hline
\end{tabular}

Sources: IMF staff estimates.

9. The extent of market loss, however, varies significantly across markets, both in terms of regions and products. Specifically:

- $\quad$ Across regional markets - Much like other advanced economies, France has lost market share in every region. Among markets in advanced economies, France's loss in the Euro Area is the most significant, given that this market accounts for half of the French exports (Table 4). Concerning emerging and developing economies, France's loss in market share is most pronounced in Africa and Middle East. To some extent, like many other advanced economies, France's loss in market shares reflects keener competition from emerging economies, particularly China, which has gained substantial market shares both in the Euro Area and elsewhere ${ }^{2}$. However, at the same

\footnotetext{
${ }^{2}$ France's loss in market share during the 2000's also reflected the appreciation of Euro.
} 
time, Germany's loss in market shares — both in the Euro Area and a few key emerging markets - has been rather limited.

\begin{tabular}{|c|c|c|c|c|c|c|c|c|c|c|c|c|c|c|c|}
\hline & \multicolumn{3}{|c|}{ France } & \multicolumn{3}{|c|}{ Germany } & \multicolumn{3}{|c|}{ Italy } & \multicolumn{3}{|c|}{ China } & \multicolumn{3}{|c|}{ USA } \\
\hline & $\begin{array}{c}\text { Ave } \\
2000-04\end{array}$ & $\begin{array}{c}\text { Ave } \\
2005-09\end{array}$ & diff & $\begin{array}{c}\text { Ave } \\
2000-04\end{array}$ & $\begin{array}{c}\text { Ave } \\
2005-09\end{array}$ & diff & $\begin{array}{c}\text { Ave } \\
2000-04\end{array}$ & $\begin{array}{c}\text { Ave } \\
\text { 2005-09 }\end{array}$ & diff & $\begin{array}{c}\text { Ave } \\
2000-04\end{array}$ & $\begin{array}{c}\text { Ave } \\
2005-09\end{array}$ & diff & $\begin{array}{c}\text { Ave } \\
2000-04\end{array}$ & $\begin{array}{c}\text { Ave } \\
\text { 2005-09 }\end{array}$ & diff \\
\hline \multicolumn{16}{|l|}{ Exports to: } \\
\hline World & 5.0 & 3.9 & -1.0 & 9.1 & 8.9 & -0.2 & 3.8 & 3.3 & -0.4 & 5.0 & 8.4 & 3.4 & 10.3 & 8.2 & -2.1 \\
\hline Advanced econ ex Euro area & 3.1 & 2.5 & -0.6 & 6.6 & 6.5 & -0.1 & 2.4 & 2.1 & -0.3 & 7.4 & 12.5 & 5.1 & 11.3 & 9.3 & -2.0 \\
\hline Euro area & 8.6 & 7.0 & -1.6 & 14.0 & 13.8 & -0.2 & 6.1 & 5.4 & -0.7 & 2.2 & 4.4 & 2.3 & 5.5 & 4.5 & -1.0 \\
\hline Africa & 14.1 & 8.8 & -5.3 & 7.7 & 5.8 & -2.0 & 5.5 & 4.3 & -1.2 & 5.2 & 9.0 & 3.8 & 6.4 & 5.1 & -1.3 \\
\hline Developing Asia & 1.5 & 1.3 & -0.2 & 3.9 & 3.8 & -0.1 & 1.2 & 1.0 & -0.2 & 3.6 & 5.4 & 1.9 & 8.3 & 6.5 & -1.8 \\
\hline Developing Europe & 1.0 & 0.9 & -0.1 & 4.4 & 4.4 & 0.0 & 1.6 & 1.5 & -0.1 & 0.7 & 1.6 & 0.9 & 0.6 & 0.6 & 0.0 \\
\hline Middle East & 6.4 & 3.8 & -2.6 & 8.2 & 6.6 & -1.6 & 6.2 & 4.8 & -1.4 & 5.8 & 8.8 & 3.0 & 9.2 & 7.8 & -1.4 \\
\hline Latin America & 2.4 & 1.7 & -0.7 & 3.7 & 3.6 & -0.1 & 2.1 & 1.8 & -0.3 & 2.6 & 6.1 & 3.5 & 38.8 & 32.1 & -6.7 \\
\hline
\end{tabular}

Sources: IMF staff estimates.

- $\quad$ Across product categories-French exports have shown a declining trend across all product categories (Figure 3). The declines in market share appear to have been more pronounced in food and beverages, industry supplies, and capital goods excluding transportation equipment. In particular, while France has traditionally had a comparative advantage on food and beverages over Germany, the latter's market share has been catching up. In other products, the decline has been less prominent. In fact, signs of slight rebound in market shares have begun to emerge in some sectors more recently, including transportation equipment and consumer goods.

\section{One plausible explanation for the loss of market share could be France's} inability to capture new fast-growing regional markets. To gauge this effect, growth of France's exports to a region is compared to the growth of the import demand of that market. The analysis suggests that:

- $\quad$ Between 2000-04 and 2005-09, the regions with fastest growth in import demand (in values) include Africa, Developing Asia, Developing Europe, and the Middle East, with growth rates being registered at around or over 20 percent (Table 5).

- While French exports to developing Asia and developing Europe ${ }^{3}$ grew significantly during that period, exports to Africa and Middle East, significantly lagged behind demand growth, reflecting the significant loss in market share in those regions.

\footnotetext{
${ }^{3}$ France's slower exports growth to emerging Europe relative to that of Germany might be due to its different strategy of off-shoring the entire production process, rather than outsourcing intermediate production stages. See Kierzenkowski (2009) as well as Fontagné and Gaulier (2008) for details.
} 
- The main explanation for France's loss in overall export market shares, however, lies in the sluggish growth in exports to the Euro Area-France's most important export market.

Figure 3 . France: Exports Market Share by Products, 1998-08 (In percent of total world exports)
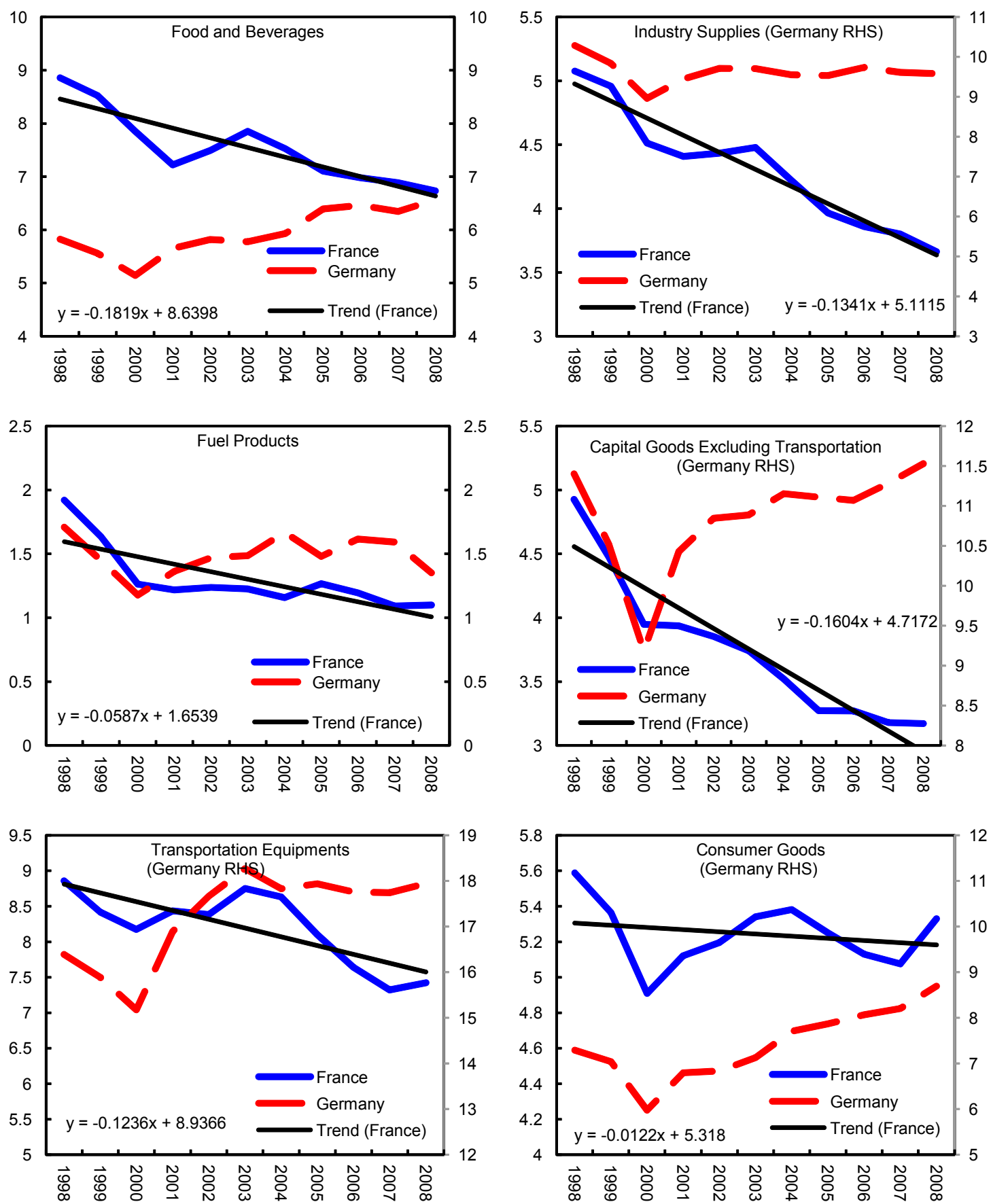

Source: UN Comtrade, IMF staff estimates. 
Table 5. Export Growth and Import Demand Growth by Regions, 2000-09 (per annum, in percent)

\begin{tabular}{|c|c|c|c|c|c|c|c|c|c|c|c|}
\hline \multirow[b]{2}{*}{$\begin{array}{l}\text { Export } \\
\text { Destination }\end{array}$} & \multirow[b]{2}{*}{$\begin{array}{c}\text { Total import } \\
\text { demand growth 1/ }\end{array}$} & \multicolumn{2}{|c|}{ France } & \multicolumn{2}{|c|}{ Germany } & \multicolumn{2}{|c|}{ Italy } & \multicolumn{2}{|c|}{ China } & \multicolumn{2}{|c|}{ USA } \\
\hline & & $\begin{array}{c}\text { export } \\
\text { growth 2/ }\end{array}$ & $\operatorname{diff} 3 /$ & $\begin{array}{l}\text { export } \\
\text { growth }\end{array}$ & diff & $\begin{array}{l}\text { export } \\
\text { growth }\end{array}$ & diff & $\begin{array}{l}\text { export } \\
\text { growth }\end{array}$ & diff & $\begin{array}{l}\text { export } \\
\text { growth }\end{array}$ & diff \\
\hline World & 13 & 8 & -5 & 12 & -1 & 10 & -3 & 25 & 12 & 8 & -5 \\
\hline Advanced econ ex Euro are: & 10 & 6 & -4 & 10 & 0 & 8 & -2 & 22 & 12 & 6 & -4 \\
\hline Euro area & 12 & 7 & -5 & 11 & 0 & 9 & -3 & 28 & 16 & 8 & -4 \\
\hline Africa & 20 & 9 & -11 & 13 & -7 & 14 & -6 & 34 & 14 & 15 & -5 \\
\hline Developing Asia & 19 & 16 & -3 & 18 & -1 & 15 & -4 & 29 & 10 & 14 & -5 \\
\hline Developing Europe & 19 & 15 & -3 & 18 & -1 & 16 & -2 & 39 & 21 & 18 & 0 \\
\hline Middle East & 22 & 9 & -12 & 16 & -5 & 16 & -6 & 33 & 11 & 19 & -3 \\
\hline Latin America & 13 & 5 & -8 & 12 & 0 & 10 & -3 & 34 & 22 & 8 & -4 \\
\hline
\end{tabular}

Sources: IMF staff estimates

$1 /$ Total demand refers to the imports to a region from the entire world, with growth calculated as the annualized growth rate from the average level of 2000-04 to the average level of 2005-09.

$2 /$ Export growth is calculated as the annualized growth rate from the average export levels of a country to a region during $2000-04$ to the average level during 2005-09.

$3 /$ Difference refers to the difference between export growth and total demand growth (discussed above). For example, French exports to the world grew by 8 percent, while world import demand grew by 13 percent, with the difference between the two growth rates being negative 5 percent. This suggests that French exports growth lagged behind total import growth by 5 percent.

\section{Price and cost competitiveness indicators portray a mixed picture for France's} competitiveness (Figure 4). Specifically,

- $\quad$ Compared to advanced economies, France's competitiveness has improved in terms of labor productivity, export prices, and unit labor costs. However, France saw a greater real appreciation - in terms of the CPI-based Real Effective Exchange Rate (REER) - relative to the United States since mid-2000s owing to the appreciation of the Euro, although this is likely to have been partly reversed with the weakening of the Euro in 2010.

- Among the four largest economies in the Euro Area, France has lost competitiveness in terms of the evolution of price/cost competitiveness indicators only to Germany while gaining competitiveness relative to Italy and Spain. More specifically, since the onset of the 2000s, France only saw a limited real exchange rate appreciation, although Germany has achieved an even smaller real appreciation during the period. Similarly, French export prices and unit labor costs have risen more slowly the average of the Euro Area, but Germany outperformed France in these respects also. Finally, labor productivity in France increased faster than the average of the Euro Area, albeit more slowly than Germany.

- $\quad$ Compared with emerging and developing economies, France saw smaller growth rates in wages (not shown in the chart) and export prices. In terms of movement in the real exchange rate, while France lost competitiveness to emerging and developing economies (notably China), before 2007, China's real exchange rate has appreciated more than that of France since 2007. That said, increases in prices in emerging economies have reflected their substantial improvement in productivity, which has 
more than offset the impact of higher prices, thereby gaining competitiveness relative to the vast majority of advanced economies, including France.

Figure 4. France: Competitiveness Indicators vis-à-vis its Competitiors, 1999-09
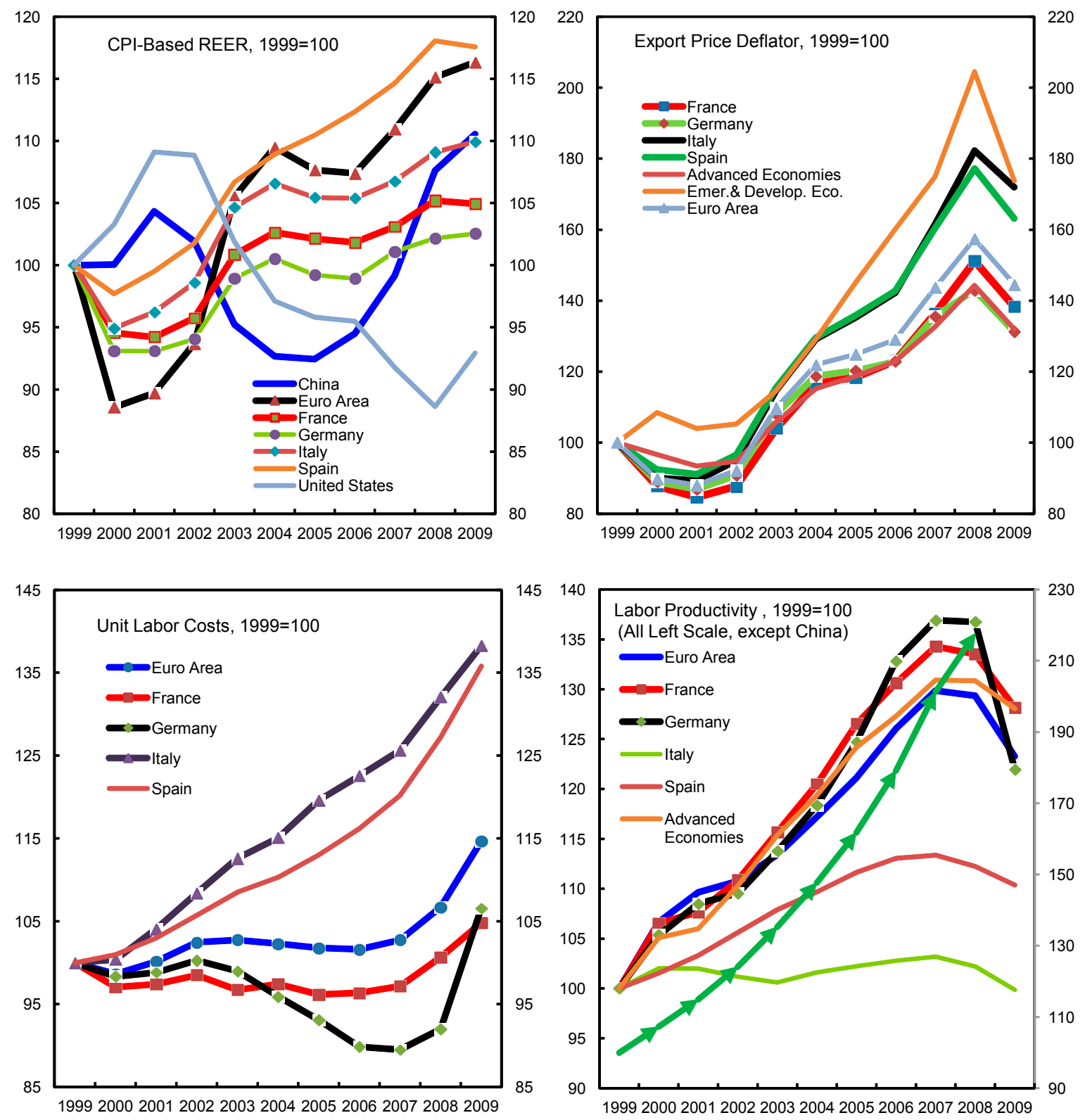

Source: IMF staff calculations.

\section{Econometric Analysis}

12. This section seeks to explain the evolution of French exports after the financial crisis with traditional determinants of trade, namely foreign demand and price competitiveness. Using an error-correction model, reduced-form equations were estimated 
in two steps: first, the long-run cointegrating relation is estimated with variables in levels (in terms of logarithm) with a trend. In the second step, short-run elasticities were estimated with variables estimated in first differences along with the error correction term from the cointegrating equation in the first step.

\section{The findings are consistent with economic intuition and all coefficients are of} the right sign. Using quarterly data during 1990-09, results of the estimation are presented in Table 6. Specifically, the results suggest:

- Every 1 percent increase in foreign demand - calculated as trade-weighted import demand of France's main export recipients - is associated with an increase in exports of around 0.9-1.0 percent in both the short run and the long run ${ }^{4}$;

- Every 1 percent increase (appreciation) in France's real effective exchange rate (REER) is associated with a decrease in French exports of around 0.25 percent in the short run and 0.65 percent in the long run.

Table 6. Determinants of Real Exports in France 1/

\begin{tabular}{|c|c|c|c|c|c|}
\hline \multicolumn{2}{|c|}{ Long-run elasticities } & \multicolumn{2}{|c|}{ Short-run elasticities } & \multirow[b]{2}{*}{$\begin{array}{l}\text { Adjustment coefficient } \\
\qquad-0.16^{\star *}\end{array}$} & \multirow[b]{2}{*}{$\begin{array}{c}\text { R-Squared } \\
0.7\end{array}$} \\
\hline $\begin{array}{c}\text { Foreign demand } \\
0.87^{\star *}\end{array}$ & $\begin{array}{l}\text { REER } \\
-0.65^{\star \star}\end{array}$ & $\begin{array}{c}\text { Foreign demand } \\
0.96^{\star *}\end{array}$ & $\begin{array}{l}\text { REER } \\
-0.25^{*}\end{array}$ & & \\
\hline $\begin{array}{l}\text { Source. IMF Staff e } \\
\text { Sample period }=199\end{array}$ & & & & & \\
\hline
\end{tabular}

14. Using the estimated coefficients, one can decompose the evolution of exports into effects due to demand, price, and other factors by rewriting the error-correction model (Figure 5). The result suggests that:

- $\quad$ During 2008:Q2-2009:Q2, France's sharp decline in exports was primarily due to a plunge in import demand from its trading partners, although the depreciation of euro has mitigated the adverse impact.

- During 2009:Q3-2009:Q4, France's recovery of exports has largely reflected the recovery of the global economy and therefore import demand of France's trading partners while, conversely, the slight strengthening of the Euro during that period has somewhat limited the export rebound.

\footnotetext{
${ }^{4}$ The size of the adjustment coefficient shows the speed at which exports return to their equilibrium value. In this case, an estimate of 0.16 implies that half of the disequilibrium is corrected in one year in France.
} 
Figure 5. Contributions to Export Growth during the Recovery

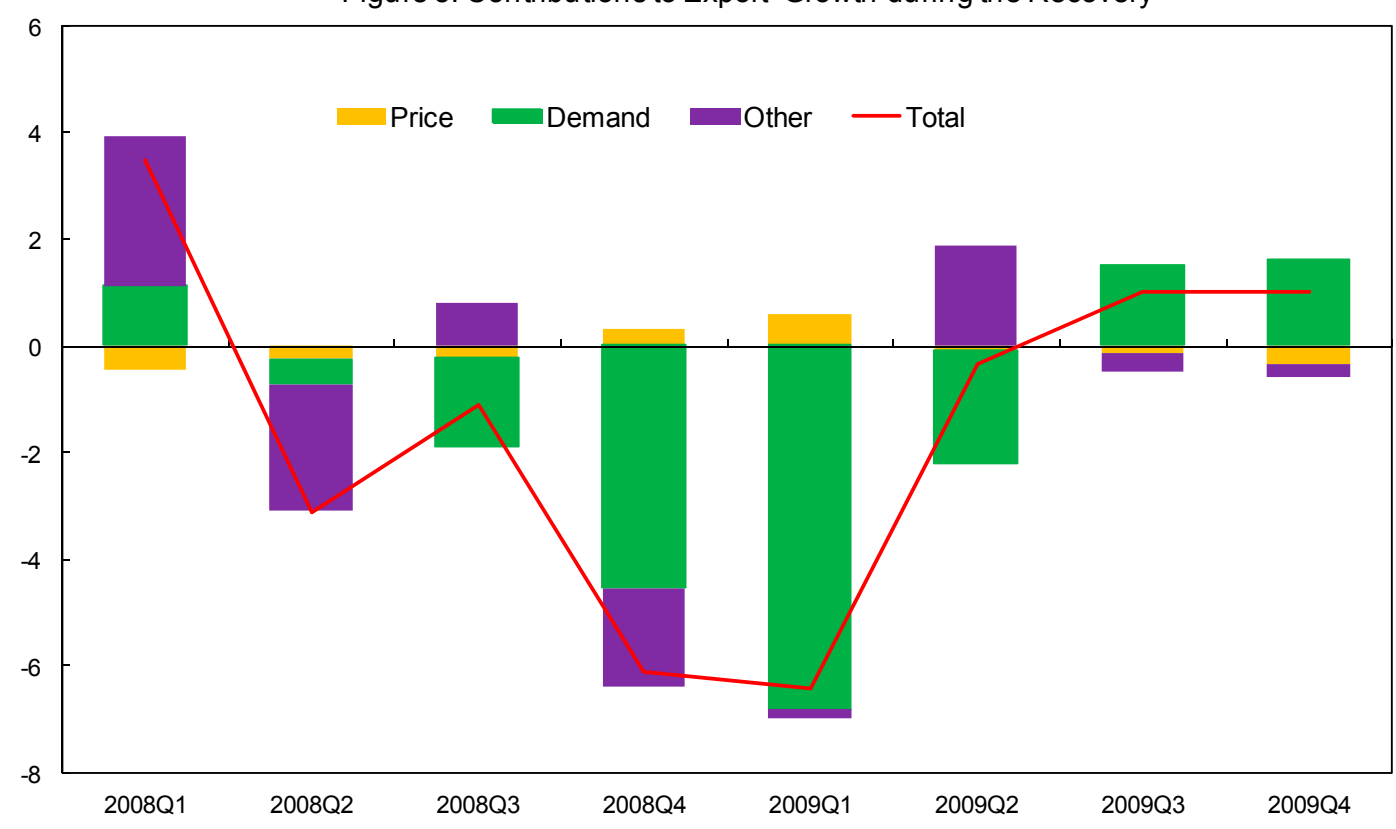

Source: IMF staff calculations

15. Over a longer time frame, however, the evolution of exports has also reflected factors other than foreign demand and the REER (Figure 6). Indeed, during the 2000s, these unexplained factors were mostly negative, suggesting loss of competitiveness due to non-price factors, which are likely related to structural issues. Part of the negative residuals could be due to outsourcing - where French firms produce goods abroad - as well as measurement errors. ${ }^{5}$ However, some of these residuals could also reflect loss of efficiency, inability to make a breakthrough in new markets, insufficient research and innovation, loss of technological edge and labor/product market

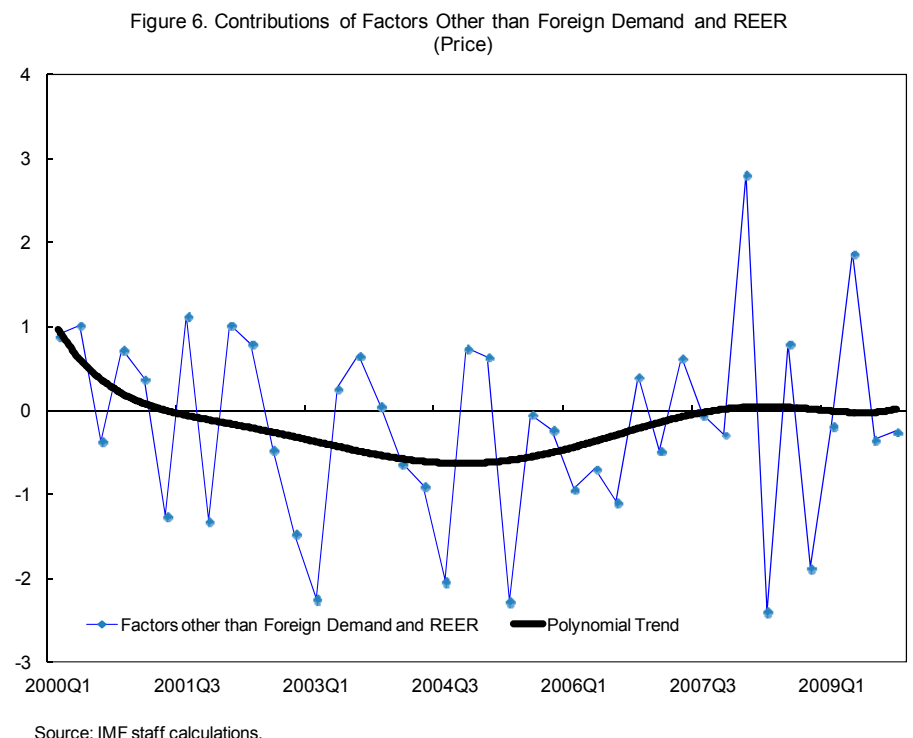
rigidities. However, as discussed in

${ }^{5}$ Specifically, unlike German firms, which outsourced intermediate stages of the production process abroad, French firms typically outsourced the entire production process, resulting in a smaller export figure. 
the previous paragraph, nonprice factors seem to have been dominated by demand factors during the recent global crisis.

\section{Looking forward, the effect of a euro depreciation on exports would depend on}

the context. A nominal depreciation would help improve France's competitiveness by correcting the overvaluation of France's real exchange rate. However, a depreciation of the euro is likely to have limited benefits on exports in the context of a collapse of confidence in the Euro Area, particularly in the absence of confidence-boosting policy measures in the Euro Area. More specifically:

- $\quad$ Exports to markets outside the Euro Area-While depreciation of the euro can have a positive price effect on French exports, the short-run elasticity of exports with respect to the real exchange rate is relatively small. Over the medium term, given that the long-run price elasticity of exports is larger, euro depreciation could have a stronger impact on net exports. ${ }^{6}$ That said, a euro depreciation is likely to be accompanied by an increase in inflation, which would partly offset some of the impact of the nominal depreciation on the real exchange rate, thereby dampening some of benefits of the real depreciation over the longer run.

- Exports to markets inside the Euro Area-Most importantly, a sharp depreciation in the context of heightened sovereign risks in the Euro Area would suppress activity and import demand of the region. In such a scenario - given that half of French exports go to the euro zone - the decline in exports to countries within the Euro Area may well offset the increase in exports to those outside the Euro Area.

\section{E. Concluding Remarks and Implications}

\section{France has been losing export market shares over the past decade, which point} to a need for corrective policy measures to boost its competitiveness, particularly vis-àvis its main competitor-Germany ${ }^{7}$. Against this background, wage moderation and structural policies to raise productivity, lower cost, and increase product and labor market flexibility are crucial. This would in turn require policies to foster research and development, promote innovation, reduce the tax burden on economic activity, boost competition, as well as create favorable conditions for doing businesses.

\footnotetext{
${ }^{6}$ Macroeconomic models used by the French authorities suggest that the net impact of a depreciation of euro on GDP is positive over the medium term.

${ }^{7}$ Fontagné and Gaulier (2008) find that the probability for a French exporter to be in competition with a German firm for the same product in the same country is very high (79\% in 2004).
} 
18. France should also strive to explore new export markets in emerging economies, where imports have been growing much faster than those in advanced economies. In particular, given that growth in advanced economies - including the Euro Area-is likely to remain sluggish in the period ahead, France's exports should reorient its focus towards emerging economies. This will require new marketing strategies and an acceleration of structural reforms to reduce costs and enhance both labor and product market flexibility, in order to allow exports to adjust more rapidly to shifts in global demand. 


\section{REFERENCES}

Economic Survey of France 2009, OECD Economics Department.

European Commission, 2010, "The Impact of the Global Crisis on Competitiveness and Current Account Divergences in the Euro Area," Quarterly Report on the Euro Area Volume 9, No.1 (2010).

Fontagné, Lionel and Guillaume Gaulier, 2008, “ Performances à l'exportation de la France et de l'Allemagne," Rapport Conseil d'Analyse Économique.

Kabundi, Alain and Francisco Nadal-De Simone, 2009, "Recent French Export Performance: Is there a Competitiveness Problem?” IMF Working Paper No. 09/2.

Kierzenkowski, Rafal (2009), "The Challenge of Restoring French Competitiveness," OECD Economics Department Working Paper. 